\title{
Civilian CASualties in Modern WARFare: The Death OF The Collateral Damage Rule
}

Valerie Epps ${ }^{*}$

\author{
TABLE OF CONTENTS
}

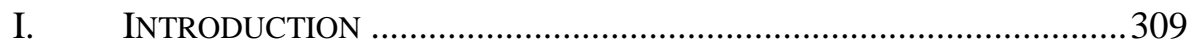

II. THE CHANGING NATURE OF WARFARE ..........................................310

A. The Threshold of War/Armed Conflict ......................................310

B. Categorizing Types of Armed Conflict ......................................312

1. Interstate Armed Conflict .................................................312

2. Armed Conflict by States Against Overseas Non-State

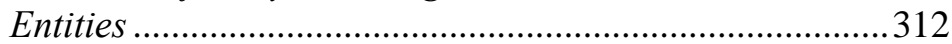

3. Internal Armed Conflict ......................................................313

C. Transnational and National Conflicts and Their

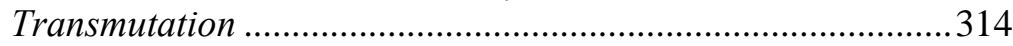

D. The Changing Prevalence of the Types of Armed Conflict .......315

1. The Prevalence of Inter-state Armed Conflicts ....................316

2. The Prevalence of Extra-territorial Armed Conflicts by

States Against Non-State Entities .......................................316

3. The Prevalence of Internal Armed Conflicts .......................317

4. Conclusions on the Prevalence of Types of Armed

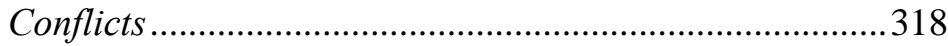

III. The SHIFTING RATIO OF Military to CiVILIAN WAR-RELATED

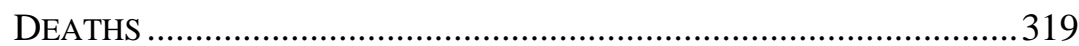

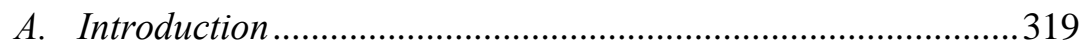

B. Problems with Compiling Data on War-Related

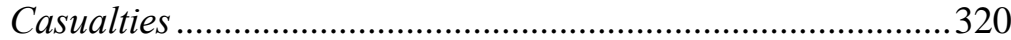

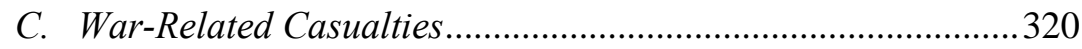

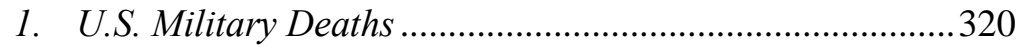

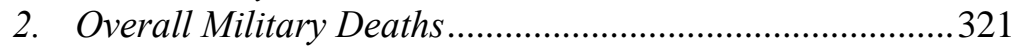

3. Civilian War-Related Deaths .............................................322

a. Problems with Data Compilation on Civilian

War-Related Deaths

\footnotetext{
* Professor of Law, Suffolk University Law School, Boston, MA.
} 
b. Problems with Calculating the Ratio of Military to Civilian War-Related Deaths .........................................325

i. $\quad$ The 10 to 1; 9 to 1 ; and 8 to 1 Ratios .....................325

ii. The Range of Acceptable Ratios of Civilian to Military War-Related Deaths..................................326

IV. The Collateral Damage Rule …….........................................329

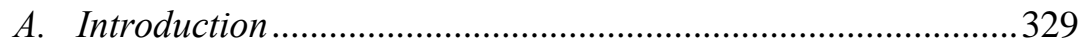

B. A Brief History of the Collateral Damage Rule ........................331

1. The Idea of Restraints on Warfare ....................................331

2. The Principle of Distinction .................................................333

3. The Formulation of the Collateral Damage Rule ...............335

a. The Prohibition on Indiscriminate Attacks...................335

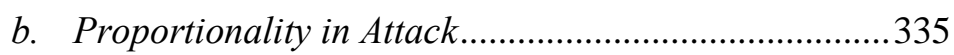

c. Precautions in Attack ..................................................336

d. Precautions Against the Effects of Attacks ....................336

C. Criticisms of, and Problems with, the Collateral Damage

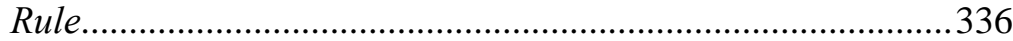

D. Does the Collateral Damage Rule Require a Direct Causal Link from Military Attack to Civilian Death or Damage to Violate the Rule?

E. Conclusion on the Protection Afforded to Civilians by the Collateral Damage Rule.

V. THE REgulatory EFFECT OF THE COllateral DAMAgE

RULE IN LIGHT OF ITS OVERALL FAILED PURPOSE ......................... 348

A. Introduction ...............................................................................348

B. The Purposes of the Collateral Damage Rule Viewed Narrowly and Broadly....

C. The Fate of Legal Rules That Cannot Fulfill Their Overall

Purposes

VI. CONCLUSION: A FEW MOdest SUgGestions to Assist the FULFILLMENT OF THE COLLATERAL DAMAGE RULE 


\section{INTRODUCTION}

Members of armed forces are sent off to war to kill enemy combatants. They are not sent off to kill civilians. Nonetheless, modern wars invariably result in far more civilian deaths than military deaths. ${ }^{1}$ This Article examines the collateral damage rule, ${ }^{2}$ one of the central operational rules regulating the conduct of hostilities, that essentially permits civilian casualties only when they are incidental to an attack on a legitimate military target. The rule is explored in light of the changing nature of warfare over the last two centuries including the shifting ratios of military to civilian warrelated deaths. The Article ultimately questions the continuing validity of this rule when, in recent decades, the overall statistics for war-related deaths reveal that civilian fatalities are considerably greater than military deaths.

The collateral damage rule, also known as the proportionality rule, is meant to offer protection to civilians in wartime and to give content to the principle of distinction in contexts where military and civilian targets are interwoven. $^{3}$ That statement reflects the usual assessment of the collateral damage rule but this Article asks whether that assessment simply tricks us into thinking that ethical military advisors, by following the rule, will in fact avoid all but incidental damage to civilians. If the many and varied studies on the ratios of civilian to military war-related deaths reveal disproportionate civilian deaths (as they do) and if the many and varied epidemiological studies reveal war-related civilian displacement, disease, deprivation, and famine (as they do), the Article asks whether the collateral damage rule has become simply an organized deceit to persuade us that condoning the combatant's privilege (permitting solders to kill enemy combatants) ${ }^{4}$ is not signing the death warrant for civilians, except "incidentally." The Article argues that in the context of modern warfare, the collateral damage rule can never accomplish what it purports to do, except in the most temporally restricted sense. It then explores what should be the fate of a legal rule that is central to the laws of armed conflict and cannot, by the nature of the context in which the rule is operative, be effective.

\footnotetext{
${ }^{1}$ See infra Part III and notes 54-124.

2 Protocol Additional to the Geneva Conventions of 12 August 1949, and Relating to the Protection of Victims of International Armed Conflict (Protocol I), art. 51, I 5(b), June 8, 1977, 1125 U.N.T.S. 3 [hereinafter API].

3 See Judith Gardam, Necessity, Proportionality and The Use of Force by States 93-94 (2004) (highlighting the definition of an indiscriminate attack and explaining the relationship between the prohibition on such attacks and the requirement of proportionality).

${ }^{4}$ Gary D. Solis, The LaW OF ARMed Conflict: InTERnAtional Humanitarian LaW in WAR 41-42 (2010).
} 
Trying to determine when there is sufficient armed violence to constitute armed conflict or war is difficult and varies depending on what is being studied. Classifying the different types of armed conflict is controversial and changes depending on the focus of the research. Quantifying military and civilian deaths in armed conflict presents multiple classification problems and much disputed or unavailable data. ${ }^{5}$ Nonetheless, despite all of these difficulties, it has become possible to discern significant trends within the last two centuries. Part II of this Article examines the changes that have taken place, over roughly the last two centuries, regarding the types of wars that occur. Part III focuses on the shifting ratio of military to civilian warrelated deaths during this period, noting that we now live in an era where wars result in a hugely disproportionate loss of civilian lives. Part IV traces the history and applicability of the collateral damage rule, also known as the proportionality rule. Part $\mathrm{V}$ brings together the data on the changes in the types of wars fought and the shift from mainly military to mainly civilian war-related deaths. Part V further asks what continuing regulatory effect the collateral damage rule can be expected to exert when the data on war-related deaths inevitably indicates that the rule has utterly failed to achieve its purpose. Part VI makes a few modest suggestions that may, in some measure, help fulfill the purpose of the collateral damage rule.

\section{THE CHANGING NATURE OF WARFARE}

\section{A. The Threshold of War/Armed Conflict}

Characterizing different types of armed conflict is difficult and different authors have taken somewhat different approaches. First, there is the question of which armed conflicts are sufficiently serious to be taken out of the category of "internal disturbances and tensions" ${ }^{\text {" }}$ and placed into the category of armed conflict. Picking which armed conflicts merit study will often depend upon the issues being researched. Many authors choose a certain level of deaths in armed conflict per year to qualify for inclusion in statistical data. For example, in their seminal book, Resort to War, Meredith Reid Sarkees and Frank Whelon Wayman use the standard of conflict that produces "1,000 [battle-related] deaths per year (or twelve month period).",

\footnotetext{
5 See infra Part III. $B$.

${ }^{6}$ Protocol Additional to the Geneva Conventions of 12 August 1949, and Relating to the Protection of Victims of Non-International Armed Conflicts (Protocol II), art. 1, 9ף 1-2, June 8, 1977, 1125 U.N.T.S. 609 [hereinafter APII].

7 Meredith Reid SarkeEs \& Frank Whelon Wayman, Resort to War: A Data Guide to InTER-STAte, Extra-State, InTRA-State, AND Non-STATE WARS, 1816-2007, at 61
} 
This was the war typology used by Singer and Small in two earlier studies, ${ }^{8}$ and is also used by authors such as R.J. Rummel ${ }^{9}$ and many others. ${ }^{10}$ It should be noted here that this typology does not address the issue of when international humanitarian law becomes applicable either to international armed conflict-also called inter-state armed conflict—or to noninternational armed conflict. That very different question is answered by examining the language of the Four Geneva Conventions: Common Article 2 (inter-state wars and occupation); Common Article 3 (conflict not of an international character); Additional Protocol I, Article 1 (inter-state wars, but including fighting against colonial domination, alien occupation, and racist regimes when exercising their right of self-determination); Additional Protocol II, Article 1 (internal armed conflicts: "Conflicts... which take place in the territory of a High Contracting Party between its armed forces and dissident armed forces or other organized armed groups" that meet certain conditions). ${ }^{11}$ Before discussing classifications of warfare, it should be noted that there is extensive literature on this issue, largely engaged in by political scientists. The categories discussed below are intended to be broadbrush categories as the overall purpose of this Article is not to support or attack any particular categorization of warfare, but rather to examine the overall changing nature of combat, particularly as it relates to the collateral damage rule.

(2010).

8 J. DaVid Singer \& Melvin SMall, The Wages of War, 1816-1965: A STATISTICAL HandbooK 32, 38-39 (1972); Melvin SMall \& J. David Singer, Resort to ARms: INTERNATIONAL AND CIVIL WAR, 1816-1980, at 46-50 (1982). These studies were part of the Correlates of War Project originally established at the University of Michigan in 1963 and now carried out at various U.S. universities. Correlates of War, History, COW, http://www. correlatesofwar/cowhistory.htm (last visited Feb. 8, 2013); Correlates of War, Ongoing Research, COW, http://www.correlatesofwar.org/ongoing.htm (last visited Feb. 8, 2013).

9 E.g., R.J. Rummel, Democracies are Less Warlike than Other Regimes, 1 EuR. J. INT'L REL. 457 (1995) (examining core studies related to war data, including those by Singer and Small).

${ }^{10}$ E.g., Jack S. Levy, Thomas C. Walker \& Martin S. Edwards, Continuity and Change in the Evolution of Warfare, in WAR IN A CHANGING WoRLD (Zeev Maoz \& Azar Gat eds., 2001). Other compilations have much lower thresholds, e.g., twenty-five annual battle deaths as adopted by Nils Petter Gleditsch et al., Armed Conflict 1946-2001: A New Dataset, 39 J. PEACE Res. 615, 617 (2002).

${ }^{11}$ Geneva Convention for the Amelioration of the Condition of the Wounded and Sick in Armed Forces in the Field, arts. 2-3, Aug. 12, 1949, 6 U.S.T. 3114, 75 U.N.T.S. 31 [hereinafter GI]; Geneva Convention for the Amelioration of the Condition of Wounded, Sick and Shipwrecked Members of Armed Forces at Sea, arts. 2-3, Aug. 12, 1949, 6 U.S.T. 3217, 75 U.N.T.S. 85 [hereinafter GII]; Geneva Convention Relative to the Treatment of Prisoners of War, arts. 2-3, Aug. 12, 1949, 6 U.S.T. 3316, 75 U.N.T.S. 135 [hereinafter GIII]; Geneva Convention Relative to the Protection of Civilian Persons in Time of War, arts. 2-3, Aug. 12, 1949, 6 U.S.T. 3516, 75 U.N.T.S. 287; API, supra note 2, art. 1; APII, supra note 6, art. 1. 


\section{B. Categorizing Types of Armed Conflict}

Using the "1,000 [battled-related] deaths per year" typology, ${ }^{12}$ wars can be characterized in a number of ways depending upon the particular focus of study. Law categorizes armed conflict into inter-state or international armed conflict (IAC) and non-international armed conflict taking place within a state. Because a number of changes have taken place in the international community, including the creation of a wider variety of entities with the capacity to wage war, a more nuanced categorization of armed conflict is necessary in order to grasp the extent of the changing nature of armed conflict. The typologies discussed below largely, but not entirely, follow the categories used by Sarkees and Wayman.

\section{Interstate Armed Conflict}

For the purposes of this Article, interstate armed conflicts are those that include state participants on both sides of the battle. Although a conflict may involve multiple parties, this Article does not seek to include or exclude such conflict on the basis of troops committed or killed, ${ }^{13}$ provided that the overall battle-related deaths in the conflict amount to at least 1,000 and that most of the fighting is carried out by state entities. Non-state entities, such as colonies, non-autonomous territories, and organized armed groups may well take part in such conflicts, but the state entities must be engaged in the bulk of combat activities. ${ }^{14}$

\section{Armed Conflict by States Against Overseas Non-State Entities}

There are two types of conflict with overseas non-state entities. In the first type, a state engages in armed conflict with a dependent entity situated outside the state's territorial boundaries, such as a colony, protectorate, special territory, mandate territory, or dependency. ${ }^{15}$ Frequently these

\footnotetext{
12 SARKEES \& WAYMAN, supra note 7.

13 States are sometimes qualified as war participants if they meet either of the following thresholds: 100 fatalities or 1,000 troops in active combat roles. Id.

${ }^{14} \mathrm{Id}$. at $61-62$.

15 Examples include the French/Algerian War (1954-1962), which led to Algerian independence from France; The Franco-Vietnamese War (1946-1954), which led to the withdrawal of France from Vietnam and the partition of Vietnam into North Vietnam and South Vietnam. See generally Raphaelle Branche, Torture and Other Violations of the Law by the French Army During the Algerian War, in GENOCIDE, WAR CRIMEs \& THE West: History AND COMPlicity 134 (Adam Jones ed., 2004); Yves BEIGBEDER, JudGing WAR

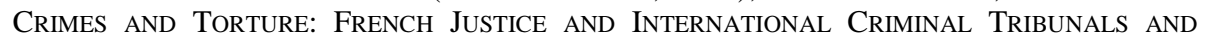
COMMISSIONS (1940-2005), at 61-77 (2006) (providing a brief history of the Franco-
} 
conflicts will involve combat designed either to curb or to achieve independence from the controlling state. ${ }^{16}$ The second type of conflict involving non-state entities arises when a state is engaged in combat against a non-state entity, such as Al Qaeda, where that entity has not been under the power or control of the state party to the conflict. ${ }^{17}$ In this context, the aims of the non-state entity may well include preventing the state participant from wielding military or other economic power in certain parts of the globe but does not focus on gaining political statehood for itself. Authorities, such as Sarkees and Wayman, describe this type of conflict as "extra-state war."18

\section{Internal Armed Conflict}

Internal armed conflicts, also known as non-international armed conflicts (NIAC), occur within the boundaries of a particular state. There are various types of these conflicts. One is a civil war in which an established state government's armed forces are fighting against an organized group or groups within the state's territory when such groups are capable of sustained military activity. ${ }^{19}$ The requirement that the non-state entity should be capable of sustained military activity is used principally to distinguish sustained military activities from short-lived outbursts of violence such as sudden massacres or sporadic riots where the death toll may well be more than 1,000 but there is no systematic organization within or between the attacking groups. ${ }^{20}$ Additional Protocol II, which applies to NIAC, includes an organizational requirement as part of its first article, explaining when the Protocol is applicable:

This Protocol ... [applies] to all armed conflicts ... which take place in the territory of the High Contracting Party between its armed forces and dissident armed forces or other organized armed groups which, under responsible command, exercise such control over part of its territory as to enable them to carry

\footnotetext{
Vietnamese War and international response).

16 SARKEES \& WAYMAN, supra note 7, at 193.

17 See id. at 63. Since the September 11, 2001 bombings in the U.S. by Al Qaeda-a nonstate, Sunni Muslim, paramilitary, international organization-the United States has systematically attacked Al Qaeda targets.

${ }^{18} I d$.

${ }^{19} I d$. at 65-66. Difficult issues can arise when civil wars result in power shifts, such as when an existing government is largely ousted from power by a rebel group and some members of the international community recognize the rebels as the new government while others continue to support the earlier government.

${ }^{20} I d$.
} 
out sustained and concerted military operations and to implement this Protocol. ${ }^{21}$

Other forms of internal armed conflict occur within a state when different non-state entities fight each other but are not engaged in combat against the central government. Sometimes a regional or substate government may be engaged in combat with rebel groups; sometimes none of the fighting entities will be connected with any governing authority. ${ }^{22}$

\section{Transnational and National Conflicts and Their Transmutation}

Inter-state armed conflict will, of course, take place between at least two states and possibly more, but where non-state entities are involved the exact nature of the conflict may be called into question. Where rebel groups are fighting a central or substate government, the combat is likely to be contained within the territory of a particular state, although sympathizers from other states may join the fight. ${ }^{23}$ Non-state armed groups may carry on armed activities in a number of different states simultaneously; their combat activities may be directed against state entities or against other non-state groups. $^{24}$

Armed conflict categories are seldom static. Conflict can start out in one category of combat and change over time into another category. The category of conflict may change several times during the course of a war. Fighting in one part of a state's territory may be designated as a particular category of conflict while fighting in another part of the state's territory is categorized differently. The International Criminal Tribunal for the Former

${ }^{21}$ APII, supra note 6, art. 1, ๆ 1 . However, Additional Protocol I-the title of which states that it relates to "the Protection of Victims of International Armed Conflict" - states that it also applies to certain forms of internal conflict:

[A]rmed conflicts in which peoples are fighting against colonial domination and alien occupation and against racist regimes in the exercise of their right of self-determination .... .

API, supra note 2 , art. 1 , ๆ 4 .

This requirement for application of Protocol I, unlike the similar section in Protocol II, does not demand any particular level of organization other than a declaration of purpose within the scope of the above definition. This would only require some level of communication sufficient to pursue the purpose.

22 SARKEES \& WAYMAN, supra note 7, at 485. For a list of all wars by classification, see $i d$. at $579-94$.

${ }^{23} I d$. at 337-40 (noting the shrinking distinction between activities in inter-state and intrastate conflict, explaining civil wars generally, and describing the consequences of external intervention).

${ }^{24}$ Id. at 485; see also id. at 46 tbl.2.1 (listing COW war typologies including those for nonstate wars). 
Yugoslavia has noted this mutability phenomenon in Prosecutor v. Duško Tadić:

It is indisputable that an armed conflict is international if it takes place between two or more States. In addition, in case of an internal armed conflict breaking out on the territory of a State, it may become international (or, depending upon the circumstances, be international in character alongside an internal armed conflict) if (i) another State intervenes in that conflict through its troops, or alternatively if (ii) some of the participants in the internal armed conflict act on behalf of that other State. $^{25}$

Indeed, in the Tadić case, the Tribunal devotes a whole section-running to fifty-seven paragraphs over twenty-six pages-to "The Legal Criteria for Establishing When, in an Armed Conflict Which is Prima Facie Internal, Armed Forces May be Regarded as Acting On Behalf of a Foreign Power, Thereby Rendering the Conflict International."26 The Tribunal also noted the disagreement that has arisen between itself and the International Court of Justice on certain issues regarding classification of armed conflict. ${ }^{27}$ The fact that armed conflicts can change from internal to international and back again, or can have both types of conflict operating alongside each other, obviously complicates the compilation of data on war classification.

\section{The Changing Prevalence of the Types of Armed Conflict}

There are many studies on the prevalence of armed conflict stretching over the last two hundred years. Sarkees and Wayman's study in Resort to War: 1816-2007 is perhaps the most comprehensive and current and this section of the Article relies heavily on their data. ${ }^{28}$

\footnotetext{
${ }^{25}$ Prosecutor v. Tadic, Case No. IT-94-1-A, Judgment, If 84 (Int’l Crim. Trib. for the Former Yugoslavia Oct. 2, 1995).

${ }^{26} I d . \S 3$.

${ }^{27}$ Id. ๆๆ 115-145 (discussing the effective control test found in Military and Paramilitary Activities in and Against Nicaragua (Nicar. v. U.S.) (Merits) 1986 I.C.J. 14, ๆף 109, 115 (June 27)).

28 SARKEES \& WAYMAN, supra note 7.
} 


\section{The Prevalence of Inter-state Armed Conflicts}

Sarkees and Wayman report that "[i]nter-state wars are relatively rare, with only ninety-five inter-state wars over the past 192 years." ${ }^{29}$ The data also reveals that the early years of the nineteenth century were relatively peaceful for this category of war. This might be explained by the low number of states at the time except for the fact that several succeeding decades (1847-1856; 1857-1866; 1877-1886) experienced a marked rise in the onset of inter-state wars although the number of states had not risen significantly. ${ }^{30}$

Beginning with the decade 1897-1906, the figures indicate that each decade experienced at least five onsets of inter-state war. ${ }^{31}$ Three decades log the highest number of inter-state war onsets with 1857-1866 having the greatest number, followed by $1967-1976$, and then by $1977-1986 .^{32}$ For the last two decades studied, 1987-1996 and 1997-2006, the number of interstate war onsets have logged in at five per decade, which equals the overall average for the entire period studied. ${ }^{33}$ One further point of interest: American, Canadian, and European scholars are sometimes (rightly) berated for their Eurocentric outlook. ${ }^{34}$ It is salient to note, therefore, that Sarkees and Wayman have undertaken a global study and the area of the world with the greatest number of inter-state wars for the period studied is Asia, followed by Europe and the Middle East. ${ }^{35}$

\section{The Prevalence of Extra-territorial Armed Conflicts by States Against} Non-State Entities

Wars that take place between a state and a non-state entity largely outside the territory of the state are "much more common than inter-state wars, with 163 ... [such] wars, compared with 95 inter-state wars . . . between 1816 and 2007. Even so,... [such] wars do not occur that frequently."36 Because these wars are fought between states and non-state entities, study figures are

${ }^{29}$ Id. at 188.

${ }^{30} \mathrm{Id}$. at $188-91$.

${ }^{31} \mathrm{Id}$. at 190 fig.3.3.

${ }^{32} \mathrm{Id}$.

${ }^{3} I$ Id.

${ }^{34}$ See id. at 45 (explaining that Sarkees and Wayman took an uncommonly expansive methodological approach to move beyond the perception of Eurocentricity evident in prior studies).

${ }^{35}$ Id. at 190 fig.3.4.

${ }^{36} I d$. at 333 (referring to these wars as "extra-state wars”). 
necessarily tied to the number of state and non-state entities with the capacity for combat.

In the decades when colonies were seeking independence the incidence of these wars rose, as it has more recently with the increase of international para-military organizations such as $\mathrm{Al}$ Qaeda. ${ }^{37}$ There was a high incidence of state versus non-state wars in the late nineteenth and early twentieth centuries when the imperial powers were fighting indigenous peoples in order to establish colonies. ${ }^{38}$ The incidence of these wars rose again in the decade from 1947-1956 which saw the start of the colonial struggle for independence. $^{39}$ After that time, the colonial powers, realizing that colonial independence was a foregone conclusion, seldom resorted to war to retain a colony. Asia is again the area of the world that has experienced the highest incidence of this type of armed conflict. ${ }^{40}$

\section{The Prevalence of Internal Armed Conflicts}

Sarkees and Wayman catalogue 335 internal armed conflicts during the period studied (1816-2007); that is more than three times the number of inter-state wars and more than double the number of extra-territorial state versus non-state wars in the same period. ${ }^{41}$ Excluded from this number are another sixty-two wars that are labeled "non-state wars." 42 These are wars that take place between non-state entities either in territory not yet under the control of a state (61 wars) or that take place across state borders (1 war). ${ }^{43}$ If we combine all of these wars into the broader category of internal armed conflicts, obviously, the numbers rise even higher. However, excluding the latter sixty-two wars, the great increase in internal armed conflict begins during the 1957-1966 decade and keeps rising until the last decade studied 1997-2006, which saw a modest decline from the highest incidence. ${ }^{44}$ Many of these internal armed conflicts became internationalized in the sense that one or more states ultimately intervened in the conflict. ${ }^{45}$

Looking at the figures for the sixty-two wars that are categorized as between non-state entities taking place either in a non-state territory or across

${ }^{37}$ Id. at 335 fig.4.3.

${ }^{38} \mathrm{Id}$.

39 Id.

${ }^{40} I d$. at 336.

${ }^{41} I d$. at 337. Sarkees and Wayman list 103 inter-state wars and mention 163 extraterritorial wars. $I d$. at 76-77 tbl.3.1, 194.

${ }^{42} I d$. at 485.

${ }^{43} I d$.

${ }^{44} I d$. at 483 fig.5.3.

${ }^{45} I d$. 
state borders, the greatest prevalence occurs during the nineteenth century in what Sarkees and Wayman refer to as the "prestate-formation" period. ${ }^{46}$ Given their definition of this category of wars, this terminology is not surprising. Africa, Asia, and the Western Hemisphere have experienced by far the greatest incidence of these sixty-two wars. ${ }^{47}$ Again, this is unsurprising given the history of colonialism and state formation.

\section{Conclusions on the Prevalence of Types of Armed Conflicts}

From the categories of armed conflict and the data discussed above, it is easy to discern that during the last two centuries, inter-state wars are the least prevalent (95); state versus non-state entities are at the mid-prevalence level (163); and internal armed conflicts top the prevalence chart (335 plus another 62, totaling 397). It is also clear that the incidence of internal armed conflicts has seen a dramatic rise since the middle of the twentieth century.

In any decade during the last two centuries, the maximum number of inter-state wars is ten. ${ }^{48}$ For extra-territorial wars between states and nonstate entities, the maximum number of wars in any decade is eighteen, with a very marked decline after 1956 - five being the maximum number for any decade since then. ${ }^{49}$ For internal armed conflicts, the pattern is wholly different. The second half of the twentieth century saw a dramatic rise in such wars. From 1957 on, every decade has seen more than twenty internal armed conflict wars, with forty internal armed conflicts during 1987-1996 and thirty-five during 1997-2006. ${ }^{50}$ As Bethany Lacina and Nils Petter Gleditsch note in an updated global combat dataset, there are "declining numbers of major interstate conflicts and internationalised[sic] civil wars .... [and] most warfare is in the form of civil conflict and wars of state failure." 51 The Human Security Report 2009/2010 comes to the same conclusion:

The overwhelming majority of armed conflicts are now fought within states. These intrastate conflicts have relatively low annual battle-death tolls on average and have made up an increasing proportion of all conflicts since the end of World

${ }^{46} I d$. at 537.

47 Id. at 540 fig.6.4.

${ }^{48} I d$. at 190 fig.3.3.

${ }^{49} \mathrm{Id}$. at 335 fig.4.3.

${ }^{50} \mathrm{Id}$. at 483 fig.5.3.

${ }^{51}$ Bethany Lacina \& Nils Petter Gleditsch, Monitoring Trends in Global Combat: A New Dataset of Battle Deaths, 21 EUR. J. PopUlation 145, 160 (2005). 
War II. In the late 1940s, they made up little over half of all conflicts; by the early 1990s, their share was closer to 90 percent. $^{52}$

However, that report also notes that: "[w]ith very few exceptions, international conflicts have been far more deadly than intrastate conflicts."

\section{The SHIFTING RATIO OF MiLITARY TO CIVILIAN WAR-RELATED DEATHS}

\section{A. Introduction}

In a 2001 study sponsored by the International Committee of the Red Cross (ICRC) the authors make the following assessment of the ratio of military to civilian deaths in modern wars:

The research reveals, in essence, that modern wars have become conflicts without limits. Civilians have-both intentionally and by accident-been moved to center stage in the theater of war, which was once fought primarily on battlefields. This fundamental shift in the character of war is illustrated by a stark statistic: in World War I, nine soldiers were killed for every civilian life lost. In today's wars, it is estimated that ten civilians die for every soldier or fighter killed in battle. ${ }^{54}$

There have been several rigorous critiques of the accuracy of this ratio, which will be discussed below, but $i^{55}$ is this shift in the ratio of military to civilian war-related deaths that is the primary focus of this section of the Article.

\footnotetext{
52 Human Security Report Project, Human Security Report 2009/2010, at 160 (2011) [hereinafter Human Security Report Project]; see also Kalevi J. Holsti, The State, WAR, AND THE STATE OF WAR (1996), available at http://www.hsrgroup.org/human-securityreports/20092010/text.aspx (detailing the growing number of intra-state wars from 1945 to 1995).

${ }^{53}$ Human Security Report Project, supra note 52, at 22 fig.1.2.

54 Stanley B. Greenberg \& Robert O. Boorstin, People On War: Civilians in the Line of Fire, PuB. PersP., Nov./Dec. 2001, at 18, 19.

${ }^{55}$ See infra Part III.C.3.b.i.
} 


\section{B. Problems with Compiling Data on War-Related Casualties}

This Article claims no in-depth knowledge of statistics and does not seek to endorse any particular method of compiling data on war-related casualties. There are many articles that assess various statistical models used for this task. $^{56}$ Each compilation tends to be idiosyncratic ${ }^{57}$ and often rely, to some extent, on data supplied by non-impartial parties to the conflicts, such as opposing military forces. The estimates of military and civilian deaths can vary widely. Some studies provide figures compiled from various databases and then estimate average or median numbers. ${ }^{58}$ Even with careful explanations and limiting provisos, it remains true that "such figures at times display enormous variance." 59 Nonetheless, through examining a variety of available reports on war casualties, broad trends are observable over time. It is these trends, discussed below, that are relevant to the argument pursued in this Article.

\section{War-Related Casualties}

\section{U.S. Military Deaths}

An examination of U.S. military deaths is instructive. In 2010, the U.S. Congressional Research Service issued a compilation of United States military war-related deaths and injuries beginning with the Revolutionary War (1775-1783) and ending with the most recent Iraq War-named Operation Iraqi Freedom (OIF)—and Afghan War-named Operation Enduring Freedom (OEF) ${ }^{60}$ The highest totals for U.S. military deaths, in declining order, occurred during World War II (WWII): 405,399; The Civil War (Union forces only): 364,511; World War I (WWI): 116,516; the

${ }^{56}$ See, e.g., Beth Osborne Daponte, Wartime Estimates of Iraqi Civilian Casualties, 89 INT'L REV. RED CROss 943 (2007) (examining multiple approaches to estimate civilian casualties for the conflict in Iraq and comparing challenges raised by these approaches).

57 By idiosyncratic I mean that a study covers statistics of one or more particular wars in a specified time frame or geographic area. The studies also differ on exactly which types of deaths are included in the data.

${ }^{58}$ See, e.g., Matthew White, Death Tolls for the Majors Wars and Atrocities of the Twentieth Century, NeCROMETRICs, http://necrometrics.com/20c1m.htm (last updated June 2011).

59 Milton Leitenberg, Deaths in Wars and Conflicts in the 20th Century 3 (3d ed. 2006), available at http://www.clingendael.nl/publications/2006/20060800_cdsp_occ_leitenb erg.pdf.

60 Anne Leland \& Mari-Jana “M-J” Oboroceanu, Cong. Research Serv., RL32492, AMERICAN War AND MilitaRy OpERATIONS CASUALTIES: ListS AND Statistics (2010). 
Vietnam Conflict: 58,220; and the Korean War: 36,574. ${ }^{61}$ The more recent U.S. wars have seen far fewer U.S. military deaths ranging from 4,365 in the Iraq War ${ }^{62}$ to 1,948 deaths in the Persian Gulf $\mathrm{War}^{63}$ and 973 in the Afghan War (through February 6, 2010).$^{64}$ Of course, if Confederate Army deaths are included in the statistics (estimates range from roughly 258,000 to roughly 289,000), ${ }^{65}$ the Civil War would have the highest number of military deaths for the United States.

What the figures above reveal is that since WWII, military deaths for U.S. soldiers have dropped dramatically. Of course, those figures are for only one armed contingent in wars that always had at least two opposing contingents and often had many military and other armed contingents. Milton Leitenberg has been compiling figures on war-related deaths for many years. In his 2006 compilation he presents figures for all deaths in wars and conflicts from 1945-2000, broken down by civilian and military deaths. ${ }^{66}$ For example, he estimates the overall military deaths in the Vietnam Conflict as 1,158,000 and in the Korean War as 1,672,000. ${ }^{67}$

\section{Overall Military Deaths}

There are a number of compilations of worldwide military deaths; Milton Leitenberg's comprehensive study covers the twentieth century. ${ }^{68}$ The Peace Research Institute, Oslo (PRIO) has released a series of "battle death" statistics, which has been updated from time to time, most recently in 2009, covering the years 1946-2008. ${ }^{69}$ Micheal Clodfelter's massive compendium of military deaths runs from 1494-2007. ${ }^{70}$ The Correlates of War Data Sets list "battle-related combatant fatalities" from 1816-2007, suffered by the

${ }^{61} I d$. at 2, 3 tbl.1.

${ }^{62} I d$. at 16 tbl.13.

63 Id. at 12 tbl.9.

${ }^{64} I d$. at 14 tbl.11. As of July 2012, the number of U.S. military deaths in Afghanistan totals 2,028, as reported by the U.S. Dept. of Defense. Names of the Dead, N.Y. TimES, July 19, 2012, at A6.

65 Compare Civil War Casualties, Civil WAR Trust (last visited Feb. 15 2013) (setting total deaths at 620,000), with Civil War Statistics, PHIL.MUNI.cz (last visited Feb. 15, 2013) (setting Confederate casualties at 289,000).

66 LEITENBERG, supra note 59, at 73-79 tbl.2.

$67 \mathrm{Id}$. at $76-77$.

${ }^{68} \mathrm{Id}$.

69 Bethany Lacina \& Gabriel Uriarte, PRIO Battle Deaths Dataset (2009), available at http://www.prio.no/sptrans/1555324504/PRIObd3.0_documentation.pdf (combining military and civilian deaths occurring in combat).

70 Micheal Clodfelter, Warfare and Armed Conflicts: A Statistical Encyclopedia OF CASUALTY AND OTHER FIGURES 1494-2007 (3d ed. 2008). 
state for inter-state wars, or suffered by each side in the case of intra-state wars and non-state wars. ${ }^{71}$ An earlier version of the data sets also lists these fatalities for extra-state wars, although thirty of these wars have been reclassified as intra-state wars and the data only runs until $1997 .^{72}$ The latest data set lists ninety-five inter-state wars, running from the Franco-Spanish War of 1823 to the invasion of Iraq in $2003 ; 7^{73} 335$ intra-state wars running from the First Caucasus War (Russia/Georgians) 1818-1822 to the Second Yemeni Cleric War (Yemen/Zaidi Muslims) 2007; ${ }^{74}$ and 62 non-state wars, running from The First Maori Tribal War of 1818-1824 to The HemdaLendu War of 1999-2005. ${ }^{75}$ The data set also includes 163 extra-state wars, running from the Allied Bombardment of Algiers of 1816 to the Iraqi Resistance, which began in 2003. ${ }^{76}$ As the criteria for inclusion in each list is the same, ${ }^{77}$ the overall battle-related combatant fatalities for each list during this period are revealing. The total fatalities for inter-state wars are 32,145,485; for extra-state wars are 2,645,294; for intra-state wars are 8,193,883; and for non-state wars (between or among non-state entities) are $255,736 .^{78}$ In a number of these wars the data is entered as unknown so that presumably the actual overall military deaths are higher than the figures reported.

\section{Civilian War-Related Deaths}

\section{a. Problems with Data Compilation on Civilian War-Related Deaths}

One problem with the various tabulations on civilian war-related casualties is that it is often impossible to discover what percentage of the

\footnotetext{
${ }^{71}$ Correlates of War, COW Wars v. 4.0, 1816-2007, COW [hereinafter COW Wars], available at http://www.correlatesofwar.org/ (follow “Available Data Sets” hyperlink; then follow "The New COW War Data, 1816 - 2007 (v4.0)" hyperlink) (last visited Feb. 15, 2013). The war data sets are now hosted at American University and The University of Michigan-Dearborn and are compiled by Meredith Reid Sarkees \& Frank Whelon Wayman. Correlates of War, Data Set Hosting Program, COW, available at http://www.correlatesofw ar.org/dataset_hosting.htm (last visited Feb. 15, 2013).

${ }_{72}$ COW Wars, supra note 71.

73 SARKEES \& WAYMAN, supra note 7, at 75, 76-77 tbl.1.1.

${ }^{74}$ Id. at $337,342-46$ tbl.5.1.

${ }^{75} \mathrm{Id}$. at 385, 487 tbl.6.1.

${ }^{76}$ Id. at 194, 195-97 tbl.4.1.

77 The criteria for inclusion is that the war "must involve sustained combat, involving organized armed forces, resulting in a minimum of 1,000 battle-related combatant fatalities within a twelve month period." COW Wars, supra note 71 (follow "Inter-State Wars Codebook.pdf” hyperlink).

${ }^{78}$ Numbers calculated by author based on COW Wars, supra note 73.
} 
civilian deaths and injuries were incidental to military attacks. Many of the statistical data sets have rejected the notion of disaggregating military casualties from civilian casualties caused by military attacks. For example, Lacina and Gleditsch report on worldwide battle-deaths covering the years 1946-2002. ${ }^{79}$ By the term battle-deaths they mean to include "all people, soldiers and civilians, killed in combat." 80 Their figures are thus compilations of all persons killed in military operations during war. They report that the five wars that inflicted the largest numbers of battle-deaths in the period studied were: Vietnam War (1955-1975): 2,097,705; Korean War (1950-1953): 1,254,811; Chinese Civil War (1980-1988): 1,200,000; IranIraq War (1980-1988): 644,500; and the Afghan Civil War (1978-2002): $562,995 .^{81}$ They also recognize that many other deaths come in the wake of war "due to insecurity, displacement, deprivation, and disease."82

The public health consequences of war are also receiving considerable scholarly attention. ${ }^{83}$ Some estimates suggest that indirect effects of military conflicts on mortality may be as large as the direct effect of armed conflict. ${ }^{84}$ Governments tend to keep detailed statistics on military deaths but seldom have comprehensive civilian death statistics. Sometimes they keep statistics on their own civilian deaths (killed by the enemy) but almost never keep public statistics or estimates of civilians they have killed in the enemy country. For example, in the United States, the Congressional Research Service publishes figures on U.S. military deaths compiled by the Department of Defense ${ }^{85}$ but publishes only sporadic, limited figures on civilian deaths. $^{86}$ As Adam Roberts concludes: “despite extensive investigations in many war zones, and significant methodological development, there is still a shortage of reliable data on civilian victims of

\footnotetext{
${ }^{79}$ Lacina \& Gleditsch, supra note 51 , at $152 \mathrm{ff}$.

80 Id. at 148. The authors also state: "Measuring battle deaths answers the question of how many people were killed in military operations during a war and, therefore, it is the best measure of the scale, scope, and nature of the military engagement that has taken place.” Id.

${ }^{81}$ Id. at 154 tbl.1.

${ }^{82} \mathrm{Id}$. at 158.

83 E.g., World Health Organization, World Report on Violence and Health (Etienne G. Krug et al. eds., 2002), available at http://whqlibdoc.who.int/hq/2002/92415456 15.pdf; C.J.L. Murray et al., Armed Conflict as a Public Health Problem, 324 BRIT. Med. J. 346 (2002).

84 Murray et al., supra note 83, at 347.

85 U.S. Dep't of Def., Defense Casualty Analysis System, DMDC.OSD.MIL, https://www.dm dc.osd.mil/dcas/casualties.xhtml (last visited Feb. 17, 2013).

${ }^{86}$ See, e.g., U.S. Dep't of Def., Operation Iraqi Freedom (OIF) U.S. Casualty Status, DEFENSE.GOV, http://www.defense.gov/news/casualty.pdf (last updated Feb. 15, 2013) (including civilian casualties but only for civilian employed by Department of Defense).
} 
war."87 Beth Osborne Daponte has undertaken a careful analysis of the statistical methodologies of five different civilian war death studies, and even for the study she finds to have the "most credence," she also concludes that it presents "imperfect figures." 88

In all of the compilations there is disagreement about who should count as a civilian, and also who among those designated as civilians should be included in the statistics. Roberts distinguishes seven categories that have appeared in various compilations:

All too often, there is a lack of clarity about which of the following categories of civilian casualties are included in any given set of figures:

1. Those killed as a direct effect of war;

2. Those injured as a direct effect of war;

3. Those dying, whether during or after a war, from indirect effects of war such as disease, malnutrition and lawlessness, and who would not have been expected to die at such rates from such causes in the absence of the war;

4. Victims of one-sided violence, such as when states slaughter their own citizens in connection with war;

5. Victims of rape and other forms of sexual violence in connection with a war;

6. Those uprooted in a war - that is, refugees and Internally Displaced Persons (IDPs);

7. Those who, even after war is over, die prematurely from injuries sustained in war. ${ }^{89}$

Obviously, without agreement on which individuals to classify as civilian casualties and which categories of civilians count toward war-related deaths, the figures are problematic.

${ }^{87}$ Adam Roberts, Lives and Statistics: Are 90\% of War Victims Civilians?, 52 SURVIVAL 115, 118 (2010).

${ }^{88}$ Daponte, supra note 56, at 954-57.

${ }^{89}$ Roberts, supra note 87, at 116. 
b. Problems with Calculating the Ratio of Military to Civilian WarRelated Deaths

\section{i. The 10 to 1; 9 to 1 ; and 8 to 1 Ratios}

A number of high level studies give the ratio of military to civilian deaths in war as somewhere between 10 to 1 and 8 to 1 . For example, the 2001 ICRC study, quoted in Part III. $A$ above, states that "it is estimated that ten civilians die for every soldier or fighter killed in battle." 90 Unfortunately, this study gives no authority for that statement. Some European Union documents indicate that since 1990, 90\% of those dying in war have been civilians. ${ }^{91}$ Ruth Leger Sivard's well-known compilations estimated civilian deaths in the 1980s as $74 \%$ of total deaths and at "close to 90 percent" for the year $1990 .^{92}$ Various UN documents and reports state that civilian warrelated deaths now account for more that $90 \%$ of war deaths, ${ }^{93}$ although some have the lower estimate of $75 \%$ civilian casualties. ${ }^{94}$ Kofi Annan, Secretary-General of the UN (1997-2006), who cited the 75\% figure added that, with respect to the percentage of civilian war deaths, "no one really knows." ${ }^{25}$ Later statistics repeat these ratios, although the language often talks of civilian "casualties" or "war victims," and it is unclear whether the figures include displaced people or persons who die from causes not directly related to warfare. ${ }^{96}$ Recently, there have been some outright attacks on the 10 to 1 or 9 to 1 ratios. These ratios have been called an "urban myth" of modern warfare. ${ }^{97}$ At the same time, more studies include both military and civilian deaths in battle-deaths and give no disaggregated figures. ${ }^{98}$

${ }^{90}$ Greenberg \& Boorstin, supra note 54, at 19.

91 The European Union Institute for Security Studies, A Secure Europe in a Better World: European Security Strategy 5 (2003) (Javier Solana), available at http://www.iss.europa.eu/ uploads/media/solanae.pdf. The report was adopted by the European Council on Dec. 12, 2003. Id. at tit. p.

92 Ruth Leger Sivard, World Military and Social ExPenditures 1991, at 20 (1991).

93 U.N. Secretary-General, Promotion and Protection of the Rights of Children: Impact of Armed Conflict on Children: Rep. of the Expert of the Secretary-General, Ms. Graça Machel, II 24, U.N. Doc. A/51/150 (Aug. 26, 1996), available at http://www.unicef.org/graca/graright. htm; U.N. Dev. Programme, Human Development Rep. 1998: Consumption for Human Development 35 (1998), available at http://www.undp.org/en/reports/global/hdr1998.

94 Ditchley Foundation Lecture XXXV (June 26, 1998), available at http://www.ditchely. co.uk/conference/past-programme/1990-1999/1998/lecture-xxxv.

${ }^{95} \mathrm{Id}$.

96 See, e.g., Paul Collier et al., World Bank, Breaking the Conflict Trap: Civil WAR AND DEVELOPMENT POLICY 17-18 (2003) (noting that new military techniques in war have a tendency to and may be intended to displace civilian populations, resulting in higher casualties).

97 Human Security Centre, Human SECurity RePORT 2005: WAR AND PEACE IN THE 21ST 
After a comprehensive and rigorous examination of numerous high level studies that use the nine civilian deaths to every one military death ratio, or sometimes a slighter lower ratio of eight civilian deaths to every one military death, Roberts concludes that these figures are "based on shaky foundations." $"$ He does admit that it is possible that some conflict situations, such as the Cambodian killings (1975-1979) and the Rwandan genocide (1994), "have something close to a 9:1 ratio."100 He does not come to any conclusion about what ratio would be more accurate, but calls for "more systematic recording on casualties" and "high standards of rigour and professionalism in this work."

\section{ii. The Range of Acceptable Ratios of Civilian to Military War- Related Deaths}

Many sources can be cited to support the proposition that from the time that the distinction between soldiers and the non-military population was established-roughly the eighteenth century - to the beginning of the twentieth century, military deaths in wars generally far outnumbered civilian deaths. ${ }^{102}$ For example, Matthew White reports median estimates of military deaths in the Napoleonic Wars (1803-1815) as roughly 2 million with the median estimate for civilian deaths being roughly 1 million. ${ }^{103}$ Often there are either no figures for civilian deaths in wars before the twentieth century or sometimes civilian deaths will include deaths from epidemics, such as small pox, which admittedly may have been caused or aggravated by wartime conditions. ${ }^{104}$

CENTURY 75 (2005), available at http://www.hsrgroup.org/human-security-reports/2005/text. aspx.

98 Human SeCurity RePort Project, supra note 52, at 22 fig. 1.2.

99 Roberts, supra note 87, at 115.

$100 I d$. at 126.

${ }^{101} I d$. at 128 . Roberts also raises "the admittedly difficult question of whether parties involved in armed conflicts are now, or should in future be, under an obligation to report on numbers and possibly even names of civilian casualties, or whether the task should be left to independent bodies.” Id.

102 See. e.g., A.P.V. Rogers, Zero-Casualty Warfare, 82 InT’L REv. Red Cross 165 (2000) (noting that the advent of air power facilitated combat deeper within enemy lines where more civilians were harmed); Luc Reydams, A la Guerre Comme à la Guerre: Patterns of Armed Conflict, Humanitarian Law Responses and New Challenges, 88 InT'L ReV. Red Cross 73436 (2006) (describing the historical development of technology and the law of war, culminating in the shift form "civilian war" to "total war").

${ }^{103}$ Matthew White, Statistics of Wars, Oppression and Atrocities of the Nineteenth Century, NECROMETRICS, http://necrometrics.com/wars19dc.htm (last updated Mar. 2011).

${ }^{104} I d$. 
Many authors, including Walter Clemens and J. David Singer, support the view of the historically rising civilian death toll related to war:

From the end of the Thirty Years' War in 1648 to the French Revolution in 1789, Europe's princes fought one another with relatively small armies. France's upheavals, however, gave birth to the concept of a "nation in arms." Starting at the same time, the Industrial Revolution turned cities and factories into prime targets. In most wars of the [twentieth century], civilian deaths have outnumbered military deaths. ${ }^{105}$

Clemens and Singer have produced charts with the breakdown of military and civilian deaths of the "principal international conflicts of the past two centuries." deaths), and "[c]ivilians killed, plus soldiers who died from wounds, accidents or disease ${ }^{\text {"107 }}$ (civilian deaths). ${ }^{108}$ Although some of the nineteenth century wars had considerable civilian deaths, in virtually all of the twentieth century wars included in the charts civilian deaths outnumber military deaths, even though the civilian deaths include "soldiers who died from wounds, accidents or disease." 109 These wars include the following: WWI (1914-1918); the Russian Civil War and Russo-Polish War (1917-1921); Chaco (Bolivia-Paraguay, 1932-1935); WWII (1939-1945); the FrancoVietnam War (1945-1954) and U.S.-Vietnam War (1963-1973); ArabIsraeli Wars (1948-1949, 1967, 1973); Korean War (1950-1953); Belgian Congo (1960-1965); Angolan-Portuguese and Civil War (1961-1975; 19751995); Iraq-Iran War (1980-1988); Iraq-Kuwait-U.N. War (1990-1991). ${ }^{110}$ In the Spanish Civil War (1936-1939); and the Bangladesh-Pakistan-India War (1971) military and civilian deaths are reported as roughly equal. ${ }^{111}$ In the Sino-Japanese War (1937-1941) military deaths slightly outnumber civilian deaths. ${ }^{112}$ Only in the Mozambique-Portuguese and Civil War (1965-1975; 1975-1995); the Soviet-Afghanistan War (1979-1989) and the

\footnotetext{
105 Walter C. Clemens, Jr. \& J. David Singer, A Historical Perspective: The Human Cost of War, 282 SCI. AM. 56, 57 (June 2000); see also Sobhi Tawil, International Humanitarian Law and Basic Education, 82 InT'L REV. RED CROss 581 (2000) (noting that the number of civilian victims of conflict has grown since the Cold War era).

106 Clemens \& Singer, supra note 105, at 56.

107 Id.

108 Id. at 57.

109 Id. at 56.

${ }^{110} I d$. at $56-57$.

111 Id.

112 Id. at 56.
} 
Serbia-Croatia-Bosnia War (1991-1995) do military deaths outnumber civilian deaths. ${ }^{113}$

According to widely available statistics, during World War I (1914-1918) there were over 15 million deaths. ${ }^{114}$ Of the total deaths, approximately 8.5 million were military personnel and 6.8 million were civilians. ${ }^{115}$ It is important to note that these military figures include those combatants who died of war-related wounds as well as general diseases, but that the majority of military deaths still appear to have been the result of actual combat. ${ }^{116}$ Further, a large portion of the civilian deaths seem to be attributable to famine and disease. The majority of Russia's 2 million civilian deaths "were caused by disease. Hunger, and privation inflated and intensified by war."117 Other sources suggest that famine and disease had an even wider impact: roughly 6 million dead. ${ }^{118}$ Necrometrics, a widely quoted study, reports 8.5 million military deaths for WWI and a broad range of civilian death figures running from 5 million to 13 million, although the report admits that some of these figures include the Russian Civil War (1917-1922) and the Armenian Genocide (1915-1922), while others do not. ${ }^{119}$

Matthew White's Necrometrics estimate of World War II dead comes in at 65.6 million, which he compiled from a large number of sources; he gives the median estimate as 50 million. ${ }^{120}$ Of these deaths he estimates roughly 19.6 million military deaths and 45.9 million civilian deaths. ${ }^{121}$ The military deaths reported range from 22 to 25 million and the civilian deaths range from 40 million to 52 million, 13 to 20 million of which may be attributed to war-related disease and famine. ${ }^{122}$

The debates over the accuracy of particular statistics is often rancorous yet there appears to be universal agreement that military deaths most likely

\footnotetext{
113 Id. at 57.

114 Matthew White, Source List and Detailed Death Tolls for the Primary Megadeaths of the Twentieth Century, NECROMETRICS, http://necormetrics.com/20c5m.htm (last updated Feb. 2011).

$115 I d$. (calculating the civilian death total to a median range of 6.6-9 million deaths)

116 See Micheal Clodfelter, Warfare and Armed Conflicts: A Statistical ReFERENCE TO CASUALTy AND Other Figures, 1500-2000, at 479-83 (2d ed. 2002) (discussing WWI death figures by country, accounting for both combat and disease).

117 Id.

118 Id. at 480 .

119 White, supra note 114.

${ }^{120} \mathrm{Id}$.

121 Matthew White, National Death Tolls for the Second World War, NECROMETRICs, http:// necrometrics.com/ww2stats.htm\#ww2chart (last updated Feb. 2005).

122 World War II Casualties, WIKIPEDIA, available at http://en.wikipedia.org/wiki/World _War_II_casualites\#cite_note-1 (last updated Mar. 10, 2013).
} 
outnumbered civilian deaths in WWI, but that civilian deaths certainly outnumbered military deaths in WWII.

Ruth Leger Sivard also supports the view of rising civilian deaths:

Increasingly, civilians are the major victims of war. In the first half of [the twentieth century] they represented about 50 percent of war-related deaths. In more recent years, however, the proportion of civilians in total deaths has been rising. Wars are now more life-threatening for non-combatants than for those fighting them. In the 1960s civilians counted for 63 percent of the recorded war deaths; in the 1980s for 74 percent; and in the 1990s the rate seems to be going higher still. ${ }^{123}$

All of the above cited material includes discussion of the difficulty of compiling such statistics. Often these materials used slightly different terminology affecting whether certain deaths are included in certain categories. The numbers they report do differ somewhat, and all of them have been subjected to trenchant criticism about their statistical methodologies. $^{124}$ Nonetheless, it seems more than fair to conclude that since the turn of the twentieth century, civilian deaths have outnumbered military deaths in nearly all wars.

\section{The Collateral Damage Rule}

\section{A. Introduction}

There are two proportionality rules found in the law of armed conflict: one found in the jus ad bellum ${ }^{125}$ and the other found in the jus in bello. ${ }^{126}$ The United Nations Charter restricts the initiation of inter-state force to two instances: (1) self-defense after suffering an armed attack; ${ }^{127}$ (2) when authorized to use force by the Security Council. ${ }^{128}$ In the jus ad bellum the

\footnotetext{
${ }^{123}$ Ruth Leger Sivard, World Military And Social Expenditures 1996, at 7 (16th ed., 1996), available at http://www.ruthsivard.com.wmse96selections.html.

124 E.g., Michael Spagat et al., Estimating War Deaths: An Arena of Contestation, 53 J. CONFLICT RESOL. 934 (2009). I used to think that law professors engaged in rather acrimonious debates. Having waded through a good number of the articles attacking the figures cited, I have now concluded that social scientists far outdo the lawyers on the scale of rabid debate.

125 The law that regulates when it is permissible to initiate armed force.

126 The law that applies in armed conflict regardless of which party initiated the conflict.

127 U.N. Charter art. 51.

${ }^{128}$ Id. art. 42.
} 
proportionality rule restricts the amount of force used to that which is necessary to repel the initial illegal use of force. ${ }^{129}$ The second proportionality rule, also known as the collateral damage rule, is a central operational provision of the law of the conduct of hostilities. ${ }^{130}$ That rule emanates from the fundamental rule of distinction between military personnel (combatants) and military objects, on the one hand, and civilians and civilian objects, on the other hand. ${ }^{131}$ Civilians and civilian objects may not be attacked. ${ }^{132}$ Combatants and military objects can be attacked. ${ }^{133}$ When a combatant kills or injures an opposing combatant or destroys a military object it is not a crime under the laws of armed combat. Although civilians or civilian objects may end up being killed, injured, or destroyed in warfare, such casualties are only tolerated when the civilian destruction is incidental to an attack on a legitimate military target, and then only when the civilian casualties are not considered likely to be "excessive in relation to the concrete and direct military advantage anticipated."134 The difficulty of interpreting this rule will be covered below in Part IV.C. These two proportionally rules are usually thought of as separate although it can be argued that they are related ${ }^{135}$ and certainly both rules seek to restrain uses of force that might otherwise be thought permissible. The section below focuses on the collateral damage rule found in the jus in bello in light of the changing nature of warfare and the disproportionate loss of civilian lives.

\footnotetext{
129 The International Court of Justice (I.C.J.) mentioned this rule of proportionally as constituting a customary norm. Military and Paramilitary Activities in and Against Nicaragua (Nicar. v. U.S.) 1986 I.C.J. 14 (Merits), ๆף 176, 194. See also 2 John BASSET Moore, InTERNATIONAL LAW Digest 411-14 (1906) (quoting Daniel Webster's correspondence relating to the Caroline incident and the use of force in self-defense). Webster wrote that in order to justify the destruction of the Caroline, an American ship moored at a U.S. port, as permissible self-defense, the British would need to show that they "did nothing unreasonable or excessive; since the act, justified by the necessity of self-defence, must be limited by that necessity, and kept clearly within it.” 29 BRITISH AND FOREIGN STATE PAPERS 1138 (1857).

130 API, supra note 2.

131 Id. art. 48.

132 Id. art. 52, $\uparrow 1$.

${ }^{133} I$ Id. arts. 48, 52, ๆ 2.

134 Id. art. 51, ๆ 5(b).

135 See generally Judith Gail Gardam, Proportionality and Force in International Law, 87 AM. J. INT'L L. 391 (1993) (describing the development of the dual aspects of proportionality as arising from the idea that war is solely aimed at weakening opposing military force).
} 


\section{B. A Brief History of the Collateral Damage Rule}

\section{The Idea of Restraints on Warfare}

The idea of restraint on the methods and means of warfare finds expression in the 1868 Declaration of St. Petersburg, which provides " $\mathrm{t}]$ hat the only legitimate object which states should endeavor to accomplish during war is to weaken the military forces of the enemy."136 From this principle sprang the requirement that weapons causing "superfluous injury or unnecessary suffering" are prohibited. ${ }^{137}$ Certainly combatants are authorized to kill the enemy, but their methods are restricted to those that enhance military advantage. Causing superfluous injury, by definition, means that the injury is greater than necessary to achieving military success. Similarly, unnecessary suffering will, by definition, go beyond what is deemed sufficient to achieve military advantage.

Before the sixteenth century, "war was not only waged against States and their armies, but also against their people. As a result, civilians were at the mercy of the conquerors .... The notion that war is waged between soldiers and that the population should remain outside hostilities... became established by the eighteenth century."138 During the nineteenth century, wars were generally fought between state armies or organized armed militias, and non-combatants were relatively unaffected by the immediate consequences of warfare. ${ }^{139}$ Thus the earlier examples of limits on warfare, such as the prohibition on superfluous injury and unnecessary suffering, protect combatants rather than civilians. The prohibition on the denial of quarter, that is, not permitting the enemy to surrender and be taken prisoner, ${ }^{140}$ is another example of an early rule derived from humanitarian purposes limiting the mistreatment of combatants.

In order to protect noncombatants, the law first had to develop the definition of combatants. In other words, the law had to distinguish between

\footnotetext{
136 Declaration Renouncing the Use, in Time of War, of Explosive Projectiles Under 400 Grammes Weight. St. Petersburg, Dec. 11, 1868, 138 Consol. T.S. 297, available at http:// www.icrc.org/ihl.nsf/FULL/130?OpenDocument.

137 The modern rule is contained in API, supra note 2, art. 35, ๆ 2.

138 Id. cmt. pt. IV: § I: General Protection Against Effects of Hostilities, ๆๆ 1822, 1823 [hereinafter Commentary], available at http://www.icrc.org/ihl.nsf/WebPrint/470-750059COM?OpenDocument.

139 Geoffrey Best, Restraints on War on Land Before 1945, in RESTRAINTS ON WAR: STUDIES IN THE LiMITATION OF ARMED Conflicts 17, 27 (Michael Howard ed., 1979).

140 The modern rule is found in API, supra note 2, art. 40 ("It is prohibited to order that there shall be no survivors, to threaten an adversary therewith or to conduct hostilities on this basis.”).
} 
those people and objects that were lawful targets and those people and objects that were not to be targeted. The principle of distinction-which is fundamental to humanitarian law-once developed, could then endorse the notion that those persons or objects that could not be targeted should, as far possible, be immune from the effects of war. ${ }^{141}$

The idea of protecting certain groups from war has ancient roots. Historically, most major religions developed doctrines defining the occasions when war was justified. ${ }^{142}$ Saint Augustine developed the Roman Catholic doctrine of the "just war." 143 Islamic tradition also defined when the use of armed force was permissible. ${ }^{144}$ Most of these traditions also exempted certain categories of people from the effects of war. Priests, monks, and friars were considered entitled to "full security against the ravages of war....”145 Suárez argued for the exemption from death of mercenary soldiers taken prisoner because they could not be expected to understand the justness of the captor's cause. ${ }^{146}$ The U.S. Supreme Court ruled in the Paquete Habana case that unarmed fishing vessels were exempt from capture as prize of war by customary international law binding on the United States. ${ }^{147}$ The Court also quoted the 1785 Treaty of Amity and Commerce between the United States and Prussia, Article 23, which provided that if war broke out

all women and children, scholars of every faculty, cultivators of the earth, artisans, manufacturers, and fishermen unarmed and inhabiting unfortified towns, villages, or places, and in general all others whose occupations are for the common subsistence and benefit of mankind, shall be allowed to continue their respective employments, and shall not be molested in their persons, nor shall their houses or goods be

\footnotetext{
141 Geoffrey Best, WAR AND LAW Since 1945, at 115 (1994); see also Prosecutor v. Kupreskic et al., Case No. IT-95-16-T, Judgment, ๆף 521-522 (Int’l Crim. Trib. for the Former Yugoslavia Jan. 14, 2000), http://www.icty.org/x/cases/kupreskic/tjug/en/kuptj000114e.pdf (noting both the prohibition on harming civilians and three notable exceptions).

${ }^{142}$ See generally William V. O’Brien, The Conduct of Just and Limited War (1981) (discussing the early just-war doctrine of St. Augustine).

143 See generally R.A. Markus, Saint Augustine's Views on The "Just War," in The Church AND WAR 1 (W.J. Sheils ed., 1983).

144 Just War and Jihad: Historical and Theoretical Perspectives on War and Peace in Western and Islamic Traditions 195-96 (John Kelsay \& James Turner Johnson eds., 1991).

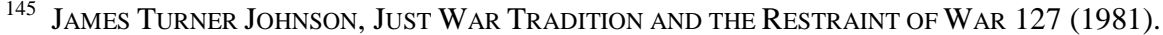

146 Arthur Nussbaum, A Concise History of the LAW OF Nations 69-70 (1947) (discussing Suárez’s study on war).

147 Paquete Habana, 175 U.S. 677, 708 (1900).
} 
burnt or otherwise destroyed, nor their fields wasted by the armed force of the enemy, into whose power, by the events of war, they may happen to fall. ... ${ }^{148}$

Certain objects were also declared protected from warfare. The Catholic Church, which had used its influence to protect priests and monks, was also successful in getting church real property and chattels protected. ${ }^{149}$ In Shakespeare's Henry $V$, Bardolph, one of the English soldiers, is hung for stealing a pyx from a church. ${ }^{150}$ Although plunder and pillage of towns and villages was condoned and widely practiced at the time, ${ }^{151}$ Henry showed restraint and ordered that "there be nothing compel[ed] from the villages, nothing taken but paid for."152 Theodor Meron's marvelous article: Shakespeare's Henry the Fifth and the Law of War, gives a detailed catalogue of the protection from war provided to persons and property in Medieval Europe, including church property, agricultural tools, and work animals. ${ }^{153}$

\section{The Principle of Distinction}

The twentieth century saw the development of aerial bombardment, particularly in World War I. ${ }^{154}$ Noncombatants were exposed to the effects of war as never before. ${ }^{155}$ Gradually, the disparate categories of persons and objects protected from war evolved into the principle of distinction. This principle requires the parties to armed conflict to distinguish between civilians and civilian objects, on the one hand, and combatants and military objectives on the other hand. ${ }^{156}$ Civilians and civilian objects may not be attacked. $^{157}$ All weapons must be of a type that can "distinguish" between categories, meaning such weapons can be aimed so as to distinguish. ${ }^{158}$ The

\footnotetext{
148 Id. at 690-91 (citing 8 Stat. 162).

149 Theodor Meron, Shakespeare's Henry the Fifth and the Law of War, 86 AM. J. INT'L L. 1, 23-24, 31-32 (1992).

${ }^{150}$ William Shakespeare, King Henry the Fifth act 3, sc. 6 (R.J. Dorius ed., 1955).

151 Meron, supra note 147, at 32.

152 SHAKESPEARE, supra note 150, at act 3, sc. 6, ll. 112-113.

153 See generally Meron, supra note 149.

154 BEST, supra note 141, at 49-50.

155 This concern is expressed in the Commentaries to API. "In view of the development of air warfare and the increasing resort to bombardment, the situation of the population remained a cause for concern ....” Commentary, supra note 138, ๆ 1842.

156 API, supra note 2, art. 48; see also Yoram Dinstein, The Conduct of Hostilities UNDER THE LAW OF INTERNATIONAL ARMED CONFLICT 82-87 (2004).

157 API, supra note 2, art. 52, ๆ 1.

158 DinsteIn, supra note 156, at 61.
} 
principle of distinction is obviously dependent on a careful definition of who or what is counted as a combatant or military objective, as opposed to who or what is counted as a civilian or civilian object. In general, combatants are members of the armed forces of a party to the conflict (except for religious and medical personnel) together with certain other persons who take a direct part in hostilities. ${ }^{159}$ Military objectives are defined broadly as follows:

those objects which by their nature, location, purpose or use make an effective contribution to military action and whose total or partial destruction, capture or neutralization, in the circumstances ruling at the time, offers a definite military advantage. $^{160}$

Civilians are those people who take no direct part in hostilities and are not members of the armed forces. ${ }^{161}$ If civilians take an active or direct part in hostilities, they lose their civilian status and all attendant protections. ${ }^{162}$ Civilian objects are defined as any object that is not a military object. ${ }^{163}$ The war contexts to which these definitions apply are also important.

Although the principle of distinction was developed in the context of inter-state warfare, it is increasingly accepted that, by custom, this distinction also applies to internal armed conflict. ${ }^{164}$ The Red Cross study of international humanitarian law discusses twenty-four rules under the heading "The Principle of Distinction." "165 Two of these rules, rules 3 and 4, which define "armed forces of a party to the conflict," only apply to international armed conflict (IAC). Of the remaining twenty-two rules, nineteen are firmly held to apply in both IAC and non-international armed conflict (NIAC). The remaining three rules are listed as applicable in IAC and arguably applicable in NIAC. ${ }^{166}$ The rules falling under the general category

159 GIII, supra note 11, art. 4(A)(1)-(2), (B).

160 API, supra note 2, art. 52, ๆ 2.

161 DinsteIn, supra note 156, at 113.

162 API, supra note 2, art. 51, I 3; see also Nils Melzer, Interpretive Guidance on the Notion of Direct Participation in Hostilities Under International Humanitarian Law, 90 INT'L Rev. RED CROSS 991, 994 (2008).

163 API, supra note 2, art. 52, 91.

164 INT'L COMM. OF THE RED CROSS, I CUSTOMARY INTERNATIONAL HUMANITARIAN LAW, ch. 1 (Jean-Marie Henckaerts \& Louise Doswald-Beck eds., 2005) [hereinafter Henckaerts \& Doswald-Beck].

${ }^{165} I d$. at pt. I.

${ }^{166} I d$. "Arguably applicable" is explained as follows: "[S]ome rules are indicated as being 'arguably' applicable because practice generally pointed in that direction but was less extensive.” Jean-Marie Henckaerts, Study on Customary International Humanitarian Law: A Contribution to the Understanding and Respect for the Rule of Law in Armed Conflict, 87 
of "The Principle of Distinction" include not only the generally required distinction discussed above, but also the prohibition on indiscriminate attacks, the collateral damage rule, the rules on precautions in attack, and precautions against the effects of attack and also the Rules on specifically protected persons. ${ }^{167}$

\section{The Formulation of the Collateral Damage Rule}

It was always understood that although civilians and civilian objects may not be attacked, the nature of warfare being what it is, some civilians and civilian objects might be killed, injured, or destroyed incidental to an attack on a military target. In order to afford even greater protection to civilians and civilian objects, a number of other rules were developed.

\section{a. The Prohibition on Indiscriminate Attacks}

Indiscriminate attacks are those attacks which are either not directed against combatants or military objectives or are unable to distinguish between military personnel and military objectives, and civilian personnel and civilian objects. ${ }^{168}$ Such attacks are prohibited, as are attacks that treat as a single military objective different military objectives located in an area interspersed by concentrations of civilians, such as cities and towns. ${ }^{169}$ This rule is applicable in both IAC and NIAC. ${ }^{170}$

\section{b. Proportionality in Attack}

The jus in bello proportionality rule, discussed above in the introduction to Part IV and now codified in Additional Protocol I (API), Article 51(5)(b), is another rule providing broader protection to civilians and civilian objects in IAC. The weight of scholarly opinion also finds this rule applicable in NIAC. ${ }^{171}$ The rule prohibits launching an attack on a military target "which may be expected to cause incidental loss of civilian life, injury to civilians, damage to civilian objects, or a combination thereof, which would be excessive in relation to the concrete and direct military advantage

\footnotetext{
Int'l Rev. Red Cross 175, 198, Annex (2005).

167 Henckaerts \& Doswald-Beck, supra note 164, at pt. I.

168 API, supra note 2, art. 51, ๆๆ 4-5.

169 Id.

${ }^{170}$ Henckaerts \& Doswald-Beck, supra note 164, at 43.

171 Id. at Rule 14; see Prosecutor v. Kupreskic et al., Case No. IT-95-16-T, Judgment, ๆ 524 (Int'l Crim. Trib. For the Former Yugoslavia Jan 14, 2000) (discussing proportional attacks in a case involving the internal conflict between Muslims and Croats in Bosnia).
} 
anticipated." ${ }^{172}$ Attacks where the collateral civilian damage is expected to be excessive in relation to the concrete and direct military advantage anticipated are classified as indiscriminate attacks. ${ }^{173}$

\section{c. Precautions in Attack}

The rules regarding precautions in attack call upon the parties to do everything possible to minimize civilian casualties. ${ }^{174}$ They must make every effort to verify that a target is a military target rather than a civilian or civilian object. ${ }^{175}$ Parties must assess whether an attack may be expected to cause incidental death or injury to civilians or damage to civilian objects that would be excessive in relation to the concrete and direct military advantage anticipated. If it is discovered that the target is not a legitimate military target or that civilian injury, death, or damage would be excessive, the attack must be canceled or suspended. ${ }^{176}$ Where any civilian loss or damage is expected, advance warning must be given, ${ }^{177}$ and when there is a choice of targets, the target likely to cause the least civilian loss or damage must be selected. ${ }^{178}$

\section{d. Precautions Against the Effects of Attacks}

The rules concerning precautions against the effects of attacks require parties to a conflict to protect civilians and civilian objects from the dangers of military operations. They must try to remove civilians and civilian objects from the area where military targets are located. ${ }^{179}$ Similarly, a party's military objects must not be located in densely populated civilian areas. ${ }^{180}$

\section{Criticisms of, and Problems with, the Collateral Damage Rule}

Ever since the collateral damage rule was articulated it has been subject to a variety of criticisms. Problems with how to weigh expected civilian casualties or civilian property damage against anticipated concrete and direct

\footnotetext{
172 API, supra note 2, art. 51, ๆ 5(b); Henckaerts \& Doswald-Beck, supra note 164, at 46.

173 API, supra note 2, art. 51, ๆ 5(b).

174 Id. art. 57, ๆ 2(a)(i); Henckaerts \& Doswald-Beck, supra note 164, at 51-67 (listing the rules on precautions in attack).

175 API, supra note 2, art. 57, ๆ 2(a)(i).

176 Id. art. 57, ๆๆ 2(a)(iii)-(b).

177 Id. art. 57, ๆ 2(c).

178 Id. art. 57, ๆ 3.

179 Id. art. 58(a).

180 Id. art. 58(b); Henckaerts \& Doswald-Beck, supra note 164, at 71.
} 
military advantage were perhaps predictable. Professor Gary Solis sums up the dilemma starkly: "On the battlefield, how is a commander to balance human life against the destruction of an enemy target? How can human lives be compared to 'things'? That is the terrible and impossible problem of proportionality."181 Questions about how to assess "excessive” civilian damage were quickly posed, and difficulties about whether the assessment of military advantage should relate to one attack, a series of attacks, or a whole campaign were debated. ${ }^{182}$ The Commentaries to API (Commentaries) try to tackle some of these issues but with commendable honesty confess that the text "is not always as clear as one might have wished." 183 They add, perhaps as an excuse, that "it seemed necessary to leave some margin of appreciation to those who will have to apply the rules. Thus their effectiveness will depend to a large extent on the good faith of the belligerents and on their wish to conform to the requirements of humanity."184 Good faith, of course, is required in the interpretation and performance of all treaties ${ }^{185}$ but if the terms of the treaty leave open a variety of possible interpretations, good faith will not ensure uniform application. Again with respect to putting these provisions into practice, the Commentaries call for "complete good faith on the part of the belligerents, as well as the desire to conform with the general principle of respect for the civilian population."

Some issues are resolved by the Commentaries. To the suggestion that API, Article 51(5)(b) might authorize any type of attack provided civilian losses were not excessive in relation to military advantage, the Commentaries boldly state that "[t]his theory is manifestly incorrect." "187 They further point out that "the attack must be directed against a military objective with means which are not disproportionate in relation to the objective."188 In other situations, the Commentaries acknowledge more ambiguity. On the issues of weighing civilian losses against military advantage, there are admitted problems: "Of course, the disproportion between losses and damages caused and the military advantages anticipated raises a delicate problem; in some situations there will be no room for doubt, while in other situations there may be reason for hesitation. In such

181 Solis, supra note 4, at 273.

182 See Commentary, supra note 138, ๆ 1976 (noting much discussion about the nature of Article 5 attacks when analyzed in relations to "concrete military advantage”).

${ }^{183}$ Id. ๆ 1835.

${ }^{184} \mathrm{Id}$.

185 Vienna Convention on the Law of Treaties, arts. 26, 31, May 23, 1969, 1155 U.N.T.S. 331.

${ }^{186}$ Commentary, supra note 138, ๆ 1978.

187 Id. ๆ 1979.

${ }^{188} \mathrm{Id}$. 
situations the interests of the civilian population should prevail. ..."189 This comment does not exactly tell us what qualifies as "excessive" civilian losses, but it does offer guidance in some situations. William Fenrick's excellent article reviewing the development of API's articles on proportionality concludes that attacks are clearly excessive when there is clear evidence that such attacks were actually directed against civilians, "but how much higher the standard is to be drawn is unclear."190 The late Leslie Green also concludes that "there is no definition as to what is 'excessive.' „191

The question of whether military advantage should be weighed against civilian damage for each individual attack, or on a cumulative basis of many attacks, or perhaps a whole campaign, has spawned different answers. Professor Farer argues that using the cumulative approach could have dire consequences for civilians. ${ }^{192}$ Professor Gardam thinks that the words concrete and direct, in conjunction with military advantage, indicate "that the Protocol requires that proportionality be assessed in relation to each individual attack, rather than on a cumulative basis."193 Professor Dinstein generally concludes that proportionality "has to be calculated in relation to a given attack, rather than on an ongoing cumulative footing." 194 However, he cautions that "[i]f an extensive air campaign is undertaken, it would be mistaken to focus on the outcome of an isolated sortie."195 The Statute of the International Criminal Court includes in its list of war crimes the intentional launch of an attack done with the knowledge that the likely collateral civilian damage will be "clearly excessive in relation to the concrete and direct overall military advantage anticipated."196 The assessment in light of overall military advantage appears to require a broader scope than simply one individual attack. Leslie Green seems to propose that either a limited campaign or the overall war effort can be an acceptable mode of assessment: "[T]he definition whether an objective is legitimate or not, depends upon the

\footnotetext{
${ }^{189} I d$.

190 William J. Fenrick, The Rule of Proportionality and Protocol I in Conventional Warfare, 98 MiL. L. REV. 91, 102 (1982).

191 Leslie C. Green, The Contemporary Law of Armed Conflict 391 (3d ed. 2008). Green continues: "The decision must be made in accordance with reasonable assessments and expectations. ..." Id.

192 Tom J. Farer, The Laws of War 25 Years After Nuremberg, 39 InT'L ConCILIATION 1, 16-17 (May 1971).

193 Judith Gail Gardam, Proportionality and Force in International Law, 87 AM. J. INT’L L. 391, 407 (1993).

${ }^{194}$ DinsteIn, supra note 156, at 123.

195 Id.

196 Rome Statute of the International Criminal Court, art. 8, ๆ 2(b)(iv), adopted July 17, 1998, 2187 U.N.T.S. 3 (emphasis added).
} 
contribution an attack upon that object will make to ultimate victory [i.e. the entire war effort] or the success of the operation of which the attack is part [i.e. the particular campaign within the wider war]."197

The International Criminal Tribunal for the former Yugoslavia (ICTY) has tackled the issue of whether the single or cumulative attack approach to proportionality is appropriate. In Prosecutor v. Kupreškić et al., the Tribunal engaged in a general discussion of the protection of civilians in armed conflict, recognizing that "deliberate attacks on civilians or civilian objects are absolutely prohibited by international humanitarian law."198 It nonetheless mentioned three exceptions to this general proscription including unavoidable collateral damage to civilians. ${ }^{199}$ The Tribunal discussed the principle of proportionality and the Martens Clause ${ }^{200}$ which requires the application of "principles of humanity" and the "dictates of public conscience" in cases not covered by treaties or, as the Tribunal states, "when interpreting and applying loose international rules."201 Weaving together the proportionality rule and the Martens Clause, the Tribunal considered whether a group of individual attacks that might each meet the proportionality requirements, might nevertheless be found violative of the laws of armed conflict when looked at cumulatively:

As an example of the way in which the Martens Clause may be utilised, regard might be had to considerations such as the cumulative effect of attacks on military objectives causing incidental damage to civilians. In other words, it may happen that single attacks on military objectives causing incidental damage to civilians, although they may raise doubts as to their lawfulness, nevertheless do not appear on their face to fall foul per se of the loose prescriptions of Articles 57 and 58 [of API] (or of the corresponding customary rules). However, in case of repeated attacks, all or most of them falling within the grey area between indisputable legality and unlawfulness, it might

\footnotetext{
197 GREEN, supra note 191.

198 Prosecutor v. Kupreskic et al., Case No. IT-95-16-T, Judgment, ๆ 521 (Int’l Crim. Trib. For the Former Yugoslavia Jan. 14, 2000).

199 Id. ๆ 522.

200 The Martens Clause was first included in the 1899 Preamble to Hague Convention II with Respect to the Laws and Customs of War on Land (available at: http://icrc.org/ihl.nsf/ FULL/150?OpenDocument) and now appears in all four Geneva Conventions and in API and APII with slightly varying language. GI, supra note 11, art. 63; GII, supra note 11, art. 62; GIII, supra note 11, art. 142; GIV, supra note 11, art. 158; API, supra note 2, art. 1, ๆ 2; APII, supra note 6 , pmbl.

${ }^{201}$ Kupreškić et al., Case No. IT-95-16-T, ๆๆ 524, 525.
} 
be warranted to conclude that the cumulative effect of such acts entails that they may not be in keeping with international law. Indeed, this pattern of military conduct may turn out to jeopardise excessively the lives and assets of civilians, contrary to the demands of humanity. ${ }^{202}$

The Tribunal's discussion in Kupreškić might well lead any military commander with authority over a broad geographic area of conflict to believe that having subordinate commanders of individual attacks engage in proportionality assessments for each attack might relieve those subordinate commanders of criminal responsibility (unless they knew or should have known of the likely effects of the overall campaign) but might not protect the commander of the overall campaign.

Yet another proportionality issue, regarding the effect of high value targets on assessing overall military advantage, has proved troublesome. Since the rule calls for balancing civilian damage against military advantage, naturally enough people have asked what happens to this balancing when it is agreed that eliminating a particular military object or combatant has an extremely high value and would result in considerable military advantage even though many civilians may have to be killed in the process. In other words, are more civilian deaths and injury or greater damage to civilian property permitted because a high value target is perceived to increase the military advantage? Dinstein accepts that the higher the military value the target holds (necessarily a subjective judgment), the higher the acceptable number of civilian losses:

Even extensive civilian casualties may be acceptable, if they are not excessive in light of the concrete and direct military advantage anticipated. The bombing of an important army or naval installation (like a naval shipyard) where there are hundreds or even thousands of civilian employees need not be abandoned merely because of the risk to those civilians. ${ }^{203}$

Solis, however, gives several hypothetical and real examples illustrating the problem of the changing ratio of civilian deaths when compared with military advantage. He asks the following questions:

\footnotetext{
${ }^{202}$ Id. $\uparrow 526$.

203 Dinstein, supra note 156, at 121.
} 
[H]ow many noncombatant lives would be acceptable forfeit for the targeting and killing of Saddam Hussein and his two sons, the three of whom were legitimate military targets? Would the anticipated direct military advantage gained by their deaths, while the international armed conflict was still in progress, mitigate the deaths of ten civilians? Twenty? A hundred? $?^{204}$

In April 2003, U.S. forces dropped four satellite-guided bombs on a Baghdad neighborhood, missing the targeted restaurant and killing as many as fourteen civilians based on apparently incorrect information that Saddam and his sons were at the location. ${ }^{205}$ Was the attack disproportional? The May 1, 2011 killing of the Al Qaeda leader, Osama bin Laden, was apparently accomplished by storming the compound where he lived in Abbotabad, Pakistan, with only four other deaths of compound residents who may or may not have been entitled to civilian status. ${ }^{206}$ Suppose instead that reliable information had finally tracked bin Laden to the compound and U.S. forces had decided to bomb the compound killing bin Laden but also killing fifty civilians, injuring sixty more and razing twenty houses in the adjacent area. Would such an attack be disproportional? Solis, apparently admitting the insolubility of the ratio calculation, commented: "Such calculations are one of the burdens of high military command."207

In some recent wars, the outrage produced by any civilian deaths has been so great that military commanders have used rules of engagement that are

\footnotetext{
204 Solis, supra note 4, at 278.

205 David Blair, Smart Bombs Aimed at Saddam Killed Families, Telegraph (Apr. 21, 2003), http://www.telegraph.co.uk/news/worldnews/middleast/Iraq/1428061/Smart-bombs-aimed-atSaddam-killed-familes.html; Jack Gruber, U.S. Bombs Site after Intelligence Says Saddam Was Meeting There, USA TODAY (Apr. 7, 2003), http://www.usatoday.com/news/world/Iraq/ 2003-04-07-war-main_x.htm.

206 Those dead were reported as one of bin Laden's sons, two of his brothers, and one of his wives. Scott Wilson et al., Osama bin Laden Killed in U.S. Raid, Buried at Sea, WAsH. Post (May 2, 2011), http://www.washingtonpost.com/national/osama-bin-laden-killed-in-us-raid-bu ried-at-sea/2011/05/02/AFx0yAZf_story.html. The issue of whether bin Laden was given the opportunity to surrender has been widely discussed. Even though Obama administration members have said that they were prepared "to take bin Laden into custody, if it were possible to do so"; Steve Coll states that the claim that capturing bin Laden was part of the Navy Seals' ROEs "is not easy to reconcile with the on-site decision to shoot bullets into his writhing body.” Steve Coll, Dead or Alive, N.Y. REv. OF BKS, Oct. 25, 2012, available at http://www. nybooks.com/articles/archives/2012/oct/25/bin-laden-dead-or-alive/?pageniation=false; Raffi Khatchadourian, Bin Laden: The Rules of Engagement,NEW YORKER (May 4, 2011), http:// www.newyorker.com/online/blogs/newsdesk/2011/05/bin-laden-the-rules-of-engagement. html.

207 Solis, supra note 4, at 280.
} 
considerably stricter than required by proportionality. ${ }^{208}$ Before the internet, smart phones, and the ever growing battery of social media communication systems, the only people that would likely know what happened in a particular attack or campaign in remote areas were those directly involved. Even in populated areas, the number of people with knowledge of the event would likely be very limited. That has now changed fundamentally. First, it seems as if almost no act, however small and possibly insignificant, takes place outside the range of some recording system. As soon as there is an explosion, riot, or weapon discharge, photographs and sound recordings rapidly find their way onto all sorts of media outlets, and soon the whole world can view the event. ${ }^{209}$ This phenomenon allows civil society to express its views as never before; the death of one civilian can mobilize thousands. ${ }^{210}$ During the U.S. invasion of Iraq in 2003, civilian deaths were antagonizing the Iraqi population to a great extent. United States policy at the time was to have the Secretary of Defense, Donald Rumsfeld, personally approve any attack where it was estimated that thirty or more civilians might be killed. ${ }^{211}$

More recently, civilian deaths in Afghanistan have been viewed as so antithetical to the overall military mission that the Rules of Engagement (ROE) have severely limited attacks where any civilian deaths are expected. $^{212}$ Colonel Clay Hall, who has served in both Iraq and

\footnotetext{
208 See infra note 212.

209 For example, the riots following the self-immolation of a Tunisian fruit and vegetable seller were posted on Facebook and led to further riots in Tunisia and elsewhere. Witnesses Report Rioting in Tunisian Town, REUTERS (Dec. 19, 2010), http://www.reuters.com/article/2 010/12/19/ozatp-tunisia-riot-idAFJOEB106U20101219; Tunisia: 11 Die in New Clashes After Weeks of Unrest, GUARDIAN (Jan. 9, 2011), http://www.guardian.co.uk/world/2011/jan/09/Tu nisia-clashes-weeks-unrest.

${ }^{210}$ In December 2010, a Tunisian man burned himself to death in protest after police confiscated the fruit and vegetables he was selling; that act is widely seen as giving rise to the revolt in Tunisia and other Arab nations. Gary Blight et al., Arab Spring: An Interactive Timeline of Middle East Protests, GuARDIAN (Jan. 5, 2012), http://www.guardian.co.uk/world/ interactive/2011/mar/22/middle-east-protest-interactive-timeline.

${ }^{211}$ Michael R. Gordon \& Bernard E. Trainor, Cobra II 89 (2006).

212 The ROE for troops in Afghanistan are classified but were widely reported as put in place by General Stanley McChrystal in 2009 and were aimed at limiting civilian casualties. Petraeus to Modify Afghanistan Rules of Engagement, Source Says, FoxNews.com (June 25, 2010), http://www.foxnews.com/politics/2010/06/25/petreus-modify-afghanistan-rules-engage ment-source-says/. Some military factions complained about the ROEs, which they claimed "have effectively forced the troops to fight with one hand tied behind their backs." Id. These ROEs were apparently revised in February 2010 to further limit tactical warfare. Sarah Holewinski \& James Morin, Afghanistan War: New Rules of Engagement Don't Pit Civilians vs. Soldiers, Christian SCI. Monitor (Mar. 10, 2010), http://www.csmonitor.com/Comment ary/Opinion/2010/0310/Afghanistan-war-New-rules-of-engagement-don-t-pit-civilians-vs.-sol diers.
} 
Afghanistan, has reportedly stated that once the goal is articulated as stabilizing the country "it's pretty hard to do that when you're dropping bombs on innocent people." 213

A recent United Nations report states that civilian deaths and injuries in Afghanistan rose by $15 \%$ from 2009 to $2010 .^{214}$ The figures are revealing: "There were 2,777 conflict-related civilian deaths in 2010 ..."215 Of course, pro-government forces $^{216}$ are only responsible for a limited proportion of such deaths and injuries, and it is estimated that the proportion of civilians killed by the pro-government forces has in fact declined from $26 \%$ in 2009 to $16 \%$ in $2010 .^{217}$ The U.N. Report, which was issued in March 2011, concludes that the number of civilian deaths has risen from 1,523 in 2007 to 2,777 in $2010 .^{218}$ In 2010, anti-government elements ${ }^{219}$ were estimated to be responsible for 2,080 of the civilian deaths, progovernment forces were responsible for 440 deaths, and 257 deaths were unattributable to any faction. 220

There has been much written about the suggestion that collateral damage is reduced through the use of precision weapons, particularly unmanned

213 Anna Mulrine, How Afghanistan Civilian Deaths Have Changed the Way the US Military Fights, Christian SCI. MONITOR (June 27, 2011), http://csmonitor.com/USA/Military/2011/ 0727/How-Afghanistan-civilian-deaths-have-changed-the-way-the-US-military-fights.

${ }^{214}$ U.N. Assistance Mission in Afg., Afghanistan Annual Report on Protection of Civilians in Armed Conflict 2010, 27-28 (Mar. 2011), http://unana.unmissions.org/Portals/UNAMA/ human\%20rights/March\%20PoC\%20Annual\%20Report\%20Final.pdf.

${ }^{215}$ Citing Rising Death Toll, UN Urges Better Protection of Afghan Civilians, UN NEws CENTRE (Mar. 9, 2011), http//www.un.org/apps/news/story.asp?NewsID=37715\&Cr=Afghan \&Cr1\#.UF8_eaTyZqc; U.N. Assistance Mission in Afg., supra note 214, at 57.

216 The U.N. Report defines as Pro-Government Forces (PGF) as follows: Afghan Government Forces. All forces that act in all military or paramilitary counter-insurgency operations and are directly or indirectly under the control of the Government of Afghanistan. These forces include, but are not limited to, the ANA [Afghan National Army], ANP [Afghan National Police], the Afghan Border Police (ABP) and the NDS [National Directorate of Security, Afghanistan's state intelligence service].

UN NEWS CENTRE, supra note 215, glossary.

217 Id. at i.

218 Id. at 57.

219 The U.N. Report defines Anti-Government Elements (AGE) as follows: [A]ll individuals and armed groups currently involved in armed conflict against the Government of Afghanistan and/or international military forces. They include those who identify as "Taliban" as well as individuals and groups motivated by a range of objectives and assuming a variety of labels including the Haqqani network, Hezb-e-Islami and al-Qaida affiliates such as the Islamic Movement of Uzbekistan, Islamic Jihad Union, Lashkari Tayyiba and Jaysh Muhammad.

Id. glossary.

${ }^{220} I d$. at 57. 
drones. $^{221}$ The legality of drone attacks, sometimes operated by non-military personnel, in countries that may not have given permission for such attacks, and that target specific people, is beyond the scope of this article. ${ }^{222}$ However, it is important to note that the accuracy of reports suggesting minimal civilian damage resulting from such attacks has been challenged, ${ }^{223}$ and in any event, the overall statistics for civilian deaths and injury generally remain disproportionate to military deaths and injury, even in wars that employ such weapons. ${ }^{224}$

\section{Does the Collateral Damage Rule Require a Direct Causal Link from Military Attack to Civilian Death or Damage to Violate the Rule?}

Causation is a slippery concept that has tested philosophers and scientist for centuries. This Article is not intended to enter into debate about the complex meaning of causation in various contexts. In general, if one action brings about a result or effect that would not otherwise have occurred, then the result or effect is said to have been caused by the earlier action. It is recognized that some effects or results are directly caused by the earlier event and that some effects or results come about by a combination of factors so that the earlier event may be said to be only an indirect cause of the later results. This general understanding of causation is quite sufficient for discussing causation in relation to the collateral damage rule largely because civilian loss and damage only needs to be incidental to the attack on the military target to fall within the ambit of the rule. ${ }^{225}$

Most of the war casualty figures, cited in Part III.C above, include military deaths and civilian deaths occurring as a direct result of combat. ${ }^{226}$ Some of the figures include other forms of military deaths, such as from

\footnotetext{
${ }^{221}$ E.g., Jane Mayer, The Predator War, NEw YoRKen, Oct. 26, 2009, at 36, available at http://www.newyorker.com/reporting/2009/10/26/091026fa_fact_mayer (discussing the risk of using unmanned drones to target terrorists).

${ }^{222}$ See generally Mary Ellen O’Connell, Unlawful Killing with Combat Drones: A Case Study of Pakistan, 2004-2009 (Notre Dame Legal Studies Paper No. 09-43, 2010), available at http://papers.ssrn.com/sol3/papers.cfm?abstract_id=1501144; Charlie Savage, U.N. Official to Ask U.S. to End C.I.A. Drone Strikes, N.Y. Times, May 28, 2010, at A8; Alston Says Drone Attacks on Pakistan-Afghanistan Border May Violate International Law, NYU LAW (Oct. 30, 2009), http://www.law.nyu.edu/news/ALSTON_UN_GENERALASSEMBLY.

${ }^{223}$ See, e.g., Scott Shane, C.I.A. Is Disputed on Civilian Toll in Drone Strikes, N.Y. TIMES, Aug. 11, 2012, at A1 (noting that the number of civilian casualties in drone strikes reported by official and unofficial sources are "so at odds that they seem to describe different events").

${ }^{224}$ See Part III.C.

225 API, supra note 2, art. 51, ๆ 5(b).

226 See, e.g., Lacina \& Gleditsch, supra note 51, at 148.
} 
disease, ${ }^{227}$ and civilian deaths, such as from general violence, social disruption, or famine associated with war. ${ }^{228}$ An argument may be made that the military cannot be held responsible for all the civilian deaths, injury, and damage that may result from the general consequences of war and that the laws of war do not ascribe culpability to the military for such overall civilian losses. The statisticians that compile battle-deaths for civilians, clearly intend to imply that the civilian deaths and damage were caused directly by combat. ${ }^{229}$ Figures relating to deaths caused by disease, famine, and general disruption are also clearly compiled by those who see these consequences as emanating from military engagements. ${ }^{230}$

When considering inter-state wars, which involve only armed forces of opposing states, it is easy to pin-point the civilian death and destruction resulting from military attacks. When dealing with intra-state wars, particularly where there are several armed factions fighting, it may be difficult to determine which armed faction caused the particular civilian destruction; nevertheless the fighting has led to the civilian devastation. ${ }^{231}$ Thus it may be concluded that civilian death and destruction come about as a result of war. Some deaths occur immediately as a result of battle. Some occur later, such as death from battle injuries and infection. Some take even longer to develop, such as deaths from widespread famine caused by general societal disruption in the wake of war. However, in a general sense, all of these statistics indicate that the civilian deaths, injuries, and property damage have been caused by war.

One interesting aspect of the collateral damage rule is that it does not prohibit direct targeting of civilians. ${ }^{232}$ That is prohibited elsewhere in API. ${ }^{233}$ What the rule prohibits in connection with attacks on military targets is "incidental loss of civilian life, injury to civilians, damage to civilian objects, or a combination thereof," when such losses are expected to "be excessive in relation to the concrete and direct military advantage

\footnotetext{
227 Clemens \& Singer, supra note 105 and accompanying text.

228 See supra notes 83-84 and accompanying text.

229 See, e.g., Lacina \& Gleditsch, supra note 51, at 148 (explaining that to limit studies to combatant deaths could seriously underplay the effects of war).

${ }^{230}$ E.g., World Health ORGAnization, supra note 83, at 218; Murray et al., supra note 83.

231 Studies demonstrate that overall societal violence rises during war, leading to more civilian death, injury, and property damage as an indirect result of the war but persisting after the end of conflict. Joris Voorhoeve, From War to the Rule of LaW: Peace Building AFTER VIOLENT CONFLICTS 105 (2007). These deaths are not generally included in war-death statistics.

232 API, supra note 2.

233 "The civilian population as such, as well as individual civilians, shall not be the object of attack.” Id. art. 51, ๆ 2.
} 
anticipated." ${ }^{234}$ The word incidental is significant but is not addressed, as such, by the Commentaries. What do we understand from the word incidental when applied to the "loss of civilian life, injury to civilians, damage to civilian objects or a combination thereof" that might be expected to result from a legitimate attack on a military target?

Dictionaries, prosaic though they are, may prove useful in aiding our understanding of the word incidental. The Oxford English Dictionary defines incidental as follows:

1.a. Occurring or liable to occur in fortuitous or subordinate conjunction with something else of which it forms no essential part; casual. ${ }^{235}$

The American Heritage Dictionary of The English Language has a similar definition:

1. Occurring or likely to occur as an unpredictable or minor consequence. ...

2. Of a minor, casual, or subordinate nature. ... ${ }^{236}$

Collins English Dictionary has three relevant definitions of incidental:

1. happening in connection with or resulting from something more important; casual or fortuitous

2. ... found in connection (with); related (to)

3. . . caused (by). ${ }^{237}$

The Merriam-Webster Dictionary entry has two definitions:

1. a: being likely to ensue as a chance or minor consequence....

2. occurring merely by chance or without intention or calculation. ${ }^{238}$

\footnotetext{
${ }^{234} I d$. art. 51, 9 5(b).

235 VII OXFORD ENGLISH DiCTIONARY 794 (2d ed. 1989), available at http://www.oed.com/ view/Entry/93467?redirectFrom=incidental\#@id.

${ }^{236}$ The American Heritage Dictionary of the English Language (5th ed. 2011), available at http://www.ahdictionary.com/.

${ }^{237}$ COLLins ENGLISH DictionaRY (7th ed. 2003), available at http://www.collinsdictionary. com/dictionary/English/incidental?showCookiePolicy=true.

${ }^{238}$ Merriam-Webster Collegiate Dictionary (11th ed. 2003), available at http://www.
} 
This dictionary also lists synonyms for "incidental”:

Synonym: casual, chance, fluky (also flukey), fortuitous, inadvertent, unintentional, unplanned, unpremeditated, unwitting. $^{239}$

It is worth noting that, with the exception of the third definition in Collins English Dictionary, none of the above definitions indicates direct causation from one event to the next. From this we may confidently conclude that the overwhelming consensus on the definition of incidental is that although an incidental event will follow an earlier event (military attack) or be associated with it, there is no requirement that the civilian death or damage incidental to the military attack be caused directly by the military attack to be prohibited. Rather, any civilian death, injury or damage that "occur[s] in fortuitous or subordinate conjunction with ... [a military attack] of which it forms no essential part...."; 240 occurs "as an unpredictable or minor consequences...."241 of a military attack; or happens "in connection with"242 a military attack, is incidental to the military attack and thus falls within the scope of the collateral damage rule. ${ }^{243}$ All of the civilian loss statistics quoted in Part III.C.3 certainly fall within the definition of occurrences incidental to military attacks. In any war, therefore, where the ratio of civilian to military deaths is at least equal, such consequences are surely excessive given the clear understanding expressed in the Commentaries that "[i]ncidental losses and damages should never be extensive”244 no matter what the military advantage might be.

\section{E. Conclusion on the Protection Afforded to Civilians by the Collateral Damage Rule}

Despite the many interpretational and operational problems with the collateral damage rule, there is little doubt that it is meant to provide protection from military attacks on civilians beyond what is required by the basic rule of discrimination and the prohibition on targeting civilians or civilian objects, or that it does so in a context where military and civilian

\footnotetext{
merriam-webster.com/dictionary/incidental.

${ }^{239}$ Id.

240 VII OXFORD ENGLISH DiCTIONARY, supra note 235.

241 The AMERICAN HeRITAge Dictionary OF THE ENGLiSh LANGUAGE, supra note 236.

242 COLLINS ENGLish DiCTIONARY, supra note 237.

243 See sources cited supra notes 172-75.

244 Commentary, supra note 138, 91980 , and text at infra notes 254-56.
} 
targets are intermeshed. Nonetheless, in an era when civilian war-related deaths are recorded as disproportionate to military deaths, the continuing validity of the rule demands further examination. ${ }^{245}$ Even in an era when high precision weapons may, in some instances, reduce civilian collateral damage, ${ }^{246}$ the overall civilian toll from warfare belies the notion that civilian war-related deaths and injuries are simply incidental (or collateral) to legitimate military destruction and death.

\section{THE REgulatory EFFECT OF THE COLLATERAL DAMAGE RULE IN LIGHT OF ITS OVERALL FAILED PURPOSE}

\section{A. Introduction}

This Article has examined the collateral damage rule in light of the changing nature of warfare and the shifting ratios of military to civilian warrelated deaths. If the overall purpose of the collateral damage rule is to protect civilians from attack in circumstances where some civilian damage may be expected, the rule does not seem to be working very well. This part of the Article will examine the purpose of the collateral damage rule viewed both narrowly and broadly. It will then examine the general question: What happens to legal rules that cannot effectuate their overall purposes? Finally, this section includes suggestions about what should happen to the collateral damage rule.

\section{B. The Purposes of the Collateral Damage Rule Viewed Narrowly and Broadly}

The title to API, Article 51 is "Protection of the Civilian Population."247 Civilians are meant to "enjoy general protection against dangers arising from military operations."248 The rules that follow in the various succeeding paragraphs are designed "[t]o give effect to this protection." ${ }^{249}$ Civilians may not be the object of an attack ${ }^{250}$ and indiscriminate attacks are prohibited. ${ }^{251}$ Various types of indiscriminate attacks are described, including those that violate the collateral damage rule. ${ }^{252}$ An attack which

245 See supra Parts III.C.2, III.C.3.b.

246 See, e.g., Shane, supra note 223.

247 API, supra note 2, art. 51, tit.

${ }^{248}$ Id. art. 51, ๆ 1.

${ }^{249} I d$.

${ }^{250} I d$. art. 51, $₫ 2$.

251 Id. art. 51, ๆ 4.

${ }^{252}$ Id. art. 51, ๆ 5(b). 
"may be expected to cause incidental loss of civilian life, injury to civilians, damage to civilian objects, or a combination thereof, which would be excessive in relation to the concrete and direct military advantage anticipated" is prohibited as indiscriminate. ${ }^{253}$

The official Commentaries to Article 51, paragraph 5(b) have already been mentioned ${ }^{254}$ but it is worth adding that the Commentaries explored the possibility that very high civilian death and damage might "be justified if the military advantage at stake is of great importance." ${ }^{255}$ The response to this suggestion was quite clear that such a view is not correct:

This idea is contrary to the fundamental rules of the Protocol; in particular it conflicts with Article 48 '(Basic Rule)' [principle of distinction] and with paragraphs 1 and 2 of the present Article 51 [general protection for civilians from dangers of military operations and prohibition on attacking civilians and on acts of violence to spread terror among civilians]. The Protocol does not provide any justification for attacks which cause extensive civilian losses and damages. Incidental losses and damages should never be extensive. ${ }^{256}$

Dinstein accuses some commentators of "confus[ing] the term 'excessive' with 'extensive' "257 and cites Claude Pilloud's and Jean Pictet's Commentary on the Additional Protocols. ${ }^{258}$ Dinstein calls this a textual misreading. ${ }^{259}$ He concludes that: "Even extensive civilian casualties may be acceptable, if they are not excessive in light of the concrete and direct military advantage anticipated."260 While Dinstein is correct that the text of API, Article 51, paragraph 5(b) uses the term excessive, Pilloud and Pictet were quite well aware of the language of the text but were making the point quoted above, namely, that even if the military advantage is great, extensive civilian casualties are never justified and always considered excessive. ${ }^{261}$

Certainly, some civilian death and damage is permissible under the rule, but it was quite clear that the application of the collateral damage rule was never expected to result in ratios where civilian deaths outnumber military

\footnotetext{
${ }^{253} I d$.

254 See supra note 138.

255 Commentary, supra note 138, ๆ 1980.

${ }^{256}$ Id. (emphasis added).

257 DinsteIn, supra note 156, at 120.

258 Commentary, supra note 138, at 626.

259 DinsteIn, supra note 156, at 121.

${ }^{260} \mathrm{Id}$.

261 See Commentary, supra note 138, ๆ 1980.
} 
deaths, or even where civilian and military deaths are equal. Civilian damage that could predictably outweigh military damage, sometimes by several multiples, was intended to be beyond the scope of permissible military activity.

Area bombardment wherein distinct military objects are located among concentrations of civilians and civilian objects is prohibited by API, Article 51, paragraph 5(a). ${ }^{262}$ The commentary on this subparagraph makes specific reference to "carpet bombing or saturation bombing."263 It also noted that there were many examples of such bombings in WWII and that they were characterized by "destroy[ing] all life in a specific area and raz[ing] to the ground all buildings situated there." ${ }^{\text {,64 }}$ The collateral damage rule, operating in concert with other protections of civilians found in this section of API, made such activity illegal.

The collateral damage rule, even if interpreted narrowly as only addressing each particular attack, ${ }^{265}$ was never meant to permit extensive civilian damage even if the military advantage was great. Particular attacks where the civilian damage is not extensive and the military advantage is concrete and direct might meet the rule's requirements, but if either the overall campaign or the war itself results in extensive civilian death, injury and damage, the collateral damage rule will have been violated. The narrow object of the rule is to protect civilians exposed to injury as part of a specific attack on a military target. The broad object of the rule is to ensure that wars do not result in extensive civilian deaths and damage. Where wars result in extensive civilian losses, which they almost always do, the collateral damage rule will have been violated many times.

\section{The Fate of Legal Rules That Cannot Fulfill Their Overall Purposes}

What happens to legal rules that are frequently violated and perceived as unable to fulfill their purposes? All law faces the problem of inefficacy, and we might look for solutions in a wide range of topics and eras. A few random examples will set the stage for thinking about approaches to this dilemma. Sometimes statutes in the area of criminal law remain on the books but are simply never enforced. Fornication, even between consenting adults, remains an offense in many developed states, but one looks in vain for its prosecution, except in theocratic states. ${ }^{266}$ In these cases we speak of

${ }^{262}$ API, supra note 2, art. 51, ๆ 5(a).

263 Commentary, supra note 138, \ 1968.

264 Id.

265 But see supra notes 192-202 (noting the tendency to reject this approach).

266 E.g., UTAH CODE ANN. § 76-7-104 (West 1953). Until recently, fornication was also a 
the law falling into desuetude. Eventually, it gets removed from the statute books.

Sometimes a rule is seen as both ineffective and encouraging other undesired consequences. In the United States, abortion was prohibited before 1973; performing or submitting to an abortion was a criminal offense except in certain instances to save the mother's life. ${ }^{267}$ When the U.S. Supreme Court ruled in Roe v. Wade ${ }^{268}$ that abortions could not be prohibited prior to roughly the last trimester of pregnancy, it did so for a number of reasons. Principally, the Court ruled that the mother's constitutionally protected right to privacy trumped any right to future life that the non-viable fetus might be thought to possess. ${ }^{269}$ Other considerations were also persuasive. Evidence was presented to the Court showing "high mortality rates at illegal 'abortion mills.' „270 Clearly, the prohibition of abortion was not working and brought in its wake the unintended consequences of killing a large number of women every year. As a result, abortion prior to the final trimester of pregnancy is now usually permitted, but must be carried out in regulated medical establishments. ${ }^{271}$

Moving away from the criminal context, the area of treaty law also provides some insight. Until recently, virtually every U.S. extradition treaty contained a political offense exception basically stating that a fugitive from justice would not be extradited for political offenses. ${ }^{272}$ The classic definition of the political offense is that a person has engaged in a crime in the course of trying to overthrow an existing government and put another government in its place. ${ }^{273}$ Such crimes could include killing police officers, or blowing up army barracks, or a whole variety of other violent crimes against the state. After it was pointed out that the United States almost never

criminal offense in Virginia, but the statute was struck down as violation of the Due Process Clause of the U.S. Constitution in Martin v. Ziherl, 607 S.E.2d 367 (Va. 2005). For examples of theocratic states criminalizing fornication, see Punishment for Non-Marital Sex in Islam: Examples of Convictions Under Sharia Law, which is available at http://www.religiousintoler ance.org/isl_adu1.htm (last updated Sept. 26, 2002).

267 TEX. PENAL CODE ANN. §§ 1191-1194, 1196 (West 1971), declared unconstitutional by Roe v. Wade, 410 U.S. 113 (1973).

268410 U.S. 113 (1973).

${ }^{269} I d$. at $153-54,163-64$.

270 Id. at 150 .

271 Id. at $163-65$.

${ }^{272}$ E.g., Extradition Treaty Between the Government of the United States of America and the Government of the United Kingdom of Great Britain and Northern Ireland, U.S.-U.K., art. V(1)(c), June 9, 1972, 28 U.S.T. 227.

${ }^{273}$ See Valerie Epps, Abolishing the Political Offense Exception, in LEgAL RESPONSES TO InTERNATIONAL TERRORISM 203, 204-05 (M. Cherif Bassiouni ed., 1988) (noting that the exception developed as a response to revolutionary action and was meant to excuse crimes deemed acceptable only because of the political beliefs of the offender). 
entered into extradition treaties with another state unless the two shared roughly the same political values, it was seen as foolish to refuse to extradite someone who attempted to overthrow a government that basically has the same political system and values as the United States. ${ }^{274}$ As a result, over the last thirty years, the United States has been systematically dropping the political offense exception clause from most of its extradition treaties.

In the area of weapons conventions, there are two cardinal rules. First, the weapon must be able to distinguish between military personnel and objects, on the one hand, and civilian personnel and objects, on the other hand. ${ }^{275}$ Second, the weapon must never cause unnecessary suffering to combatants or anyone else. ${ }^{276}$ Where a weapon is shown to violate one, or both, of these cardinal rules, the international community will draft a treaty and the weapon will be banned. ${ }^{277}$

Applying any of the solutions listed above to the collateral damage rule, however, would not solve the problem. If the rule were left as it is in the Protocol and never expected to curb military action or to be enforced (as with prohibitions on fornication), we would essential be condoning the widespread death of civilians in the wake of war. If the rule were struck down (as with the prohibition on abortion), we would be left with the principle of distinction absent the greater protection intended by the collateral damage rule. Such a solution would likely result in greater levels of civilian losses. Similarly, trying to dismantle part of the overall legal scheme deemed to have adverse consequences, like removing the political offense exception to extradition treaties, would not work because the collateral damage rule is not causing the adverse consequences-namely the large numbers of civilian casualties. Although banning the entity or action that causes the adverse consequences-banning armies or military attacks in the same way that particular weapons are banned-would, if carried out, be effective in reducing civilian causalities, one only has to articulate such a solution to know that it would be generally unacceptable.

\footnotetext{
${ }^{274} I d$. at 206.

275 Legality of the Threat or Use of Nuclear Weapons, Advisory Opinion, 1996 I.C.J. 226, I 78 (July 8). This accords with principle of distinction: API, supra note 2, art. 48.

276 API, supra note 2, art. 35, 92.

277 See, e.g., Protocol for the Prohibition of the Use of Asphyxiating, Poisonous or Other Gases, and of Bacteriological Methods of Warfare, June 17, 1925, 94 L.N.T.S. 65. Other such conventions can be found at the ICRC Document Database located at http://icrc.org/ihl.nsf/ TOPICS?OpenView\#CustomaryLaw.
} 


\section{Conclusion: A Few Modest Suggestions to Assist the FULFILLMENT OF THE COLlATERAL DAMAGE RULE}

Because of the changing nature of warfare, this Article has argued that modern warfare almost always results in extensive civilian death and damage in violation of the collateral damage rule. The current nature of warfare, therefore, makes the violation of the collateral damage rule inevitable in all but isolated examples of war. Armed forces are sent to war to destroy the enemy's armed forces (in international armed conflict) or destroy government forces or rebel forces (in internal armed conflict). They are not sent to kill civilians or damage civilian property except when civilian death or injury or civilian property damage is incidental to a legitimate attack on a military target. What happens, however, in practically all cases is that the military activity results in at least as many civilians dying and suffering injury as military personnel. Often the civilian casualties outweigh military casualties.

If we simply removed the collateral damage rule while leaving, as part of the laws of war, the prohibition on directly targeting civilians, two possible results might ensue. Any amount of civilian collateral damage would be permissible so long as it was somehow attached to an initial attack on a legitimate target. Alternatively, no amount, or possibly only very limited amounts, of civilian damage would be tolerated. Obviously, to permit widespread and extensive civilian damage that was somehow tangentially connected to a legitimate attack on military personnel or military objects would fly in the face of the long struggle to protect civilians from the effects of warfare. Indeed, it would in large measure give the green light to carpet bombing whole cities and towns with weapons of mass destruction. That way lies chaos. Similarly, ruling that no amount of civilian damage will ever be tolerated and that all attacks resulting in any civilian losses will constitute violations of the laws of war seems unrealistic and draconian as long as we allow wars and send out armies with instructions to destroy enemy combatants and other military targets.

First, we need to acknowledge that we have a problem. Despite the principle of distinction and the collateral damage rule, civilians are just as likely, or often more likely, to die in war as military personnel. Next, we need to make clear how much civilian damage is, or is not, permissible in attacks, campaigns, and overall wars. Due to nearly instantaneous media reporting of civilian death and damage, lawmakers may be galvanized to require even further restrictions on civilian losses. We know from the results of the recent ROEs in Afghanistan that commanders can significantly reduce civilian deaths. Fashioning language to accomplish further and clearer 
protections for civilians will not be easy, and gaining international agreement will take time.

Another, concurrent step we need is a clear rule requiring states and other organized fighting groups to keep "body counts" of civilian dead and injured together with inventories of civilian damage. These figures should be kept both for injuries to the state's (or fighting group's) own civilian personnel and objects and for the adversary's civilian population and civilian structures. The figures should be made public. The ICRC, or another impartial body with sufficient expertise, should also be charged with compiling similar civilian death and damage counts and publically reporting the figures.

It is widely agreed that three of the four Geneva Conventions of 1949 require states to record details of military personnel who are killed, wounded, captured, or go missing during armed conflict. ${ }^{278}$ The Fourth Geneva Convention, Relative to the Protection of Civilian Persons in Time of War, simply requires that: "As far as military considerations allow, each Party to the conflict shall facilitate the steps taken to search for the [civilians] killed and wounded, to assist the shipwrecked and other persons exposed to grave danger, and to protect them against pillage and ill-treatment.,279 Additional Protocol I, on the other hand, actually has more detailed provisions for seeking and recovering the bodies of civilians lost or killed in conflict. ${ }^{280}$ This Protocol currently has 172 parties, not including the United States. ${ }^{281}$ Additional Protocol II has a general provision requiring parties to search for and collect the dead and wounded "[w] henever circumstances permit.,282 This Protocol currently has 166 parties, again not including the United States. $^{283}$ Obviously, the Geneva Conventions and Protocols have gaps in the requirements for recording all civilian deaths and injuries in armed conflict.

In June 2011, Susan Breau and Rachel Joyce published a paper concluding that there already exists an "international legal obligation to record civilian casualties of armed conflict."284 The authors reach this

\footnotetext{
${ }^{278}$ GI, supra note 11, arts. 15-17; GII, supra note 11, arts. 18-21; GIII, supra note 11, arts. $120-121$.

${ }^{279}$ GIV, supra note 11 , art. 16.

280 API, supra note 2, arts. 33-34.

${ }^{281}$ Int'l Comm. of the Red Cross, States Party to the Following International Humanitarian Law and Other Related Traties (Nov. 15, 2012) [hereinafter Treaty Parties], http://www.icrc. org/IHL.nsf/(SPF)/party_main_treaties/\$File/IHL_and_other_related_Treaties.pdf.

${ }^{282}$ APII, supra note 6, art 8.

283 Treaty Parties, supra note 281.

284 Susan Breau \& Rachel Joyce, Discussion Paper: The Legal Obligation to Record Civilian Casualties of Armed Conflict 1 (June 2011) (unpublished manuscript), available at http://
} 
conclusion by drawing on a broad range of international documents. ${ }^{285}$ This paper was published as part of a larger effort to "build the political will to record details of every single victim of armed conflict worldwide."286 While the conclusion reached in the working paper is well argued, ${ }^{287}$ it remains true that states are not currently recording civilian war-related deaths in any systematic way. In September of 2011, The Oxford Research Group launched the Charter for the Recognition of Every Casualty of Armed Violence, which urges states and other organizations to commit to the recording of every casualty of conflict throughout the world. ${ }^{288}$ This is a bold and courageous step. The Charter may, one day, give rise to a binding treaty bringing us closer to realizing the fulfillment of the principle of distinction and the collateral damage rule; rules that, at the moment, are more often breached than observed.

www.oxfordresearchgroup.org.uk/sites/default/files/1st\%20legal\%20report\%20formatted\%20FI NAL.pdf.

285 Id. at 3.

${ }^{286}$ Oxford Research Grp., Every Casualty, available at http://www.oxfordresearchgroup. org.uk/rcac (last visited Mar. 12, 2013).

${ }_{287}$ See generally Breau \& Joyce, supra note 284.

288 For the language of the Oxford Research Group Charter, see the following link: http:// www.oxfordresearchgroup.org.uk/publications/other_media/charter. 